\title{
DOES ELIMINATING THE EARNINGS TEST INCREASE THE INCIDENCE OF LOW INCOME AMONG OLDER WOMEN?
}

\author{
Theodore Figinski \\ David Neumark \\ Working Paper 21601 \\ http://www.nber.org/papers/w21601
NATIONAL BUREAU OF ECONOMIC RESEARCH
1050 Massachusetts Avenue
Cambridge, MA 02138 \\ October 2015
}

This paper was presented at the 17th Annual Joint Meeting of the Retirement Research Consortium, August 6-7, 2015, Washington, DC. The authors gratefully acknowledge support from the Social Security Administration (SSA). The findings and conclusions are solely those of the authors and do not represent the views of SSA, the U.S. Department of the Treasury or any other agency of the federal government, or MRRC. We are grateful to Howard Iams, Richard Johnson, and Randall Mariger for helpful comments and discussions.

NBER working papers are circulated for discussion and comment purposes. They have not been peer-reviewed or been subject to the review by the NBER Board of Directors that accompanies official NBER publications.

(C) 2015 by Theodore Figinski and David Neumark. All rights reserved. Short sections of text, not to exceed two paragraphs, may be quoted without explicit permission provided that full credit, including $(\odot$ notice, is given to the source. 
Does Eliminating the Earnings Test Increase the Incidence of Low Income Among Older Women? Theodore Figinski and David Neumark

NBER Working Paper No. 21601

October 2015, Revised April 2016

JEL No. H2,J14,J22

\section{ABSTRACT}

Reducing or eliminating Social Security's Retirement Earnings Test (RET) can encourage labor supply of older individuals receiving benefits. However, these reforms can encourage earlier claiming of Social Security benefits, permanently lowering future benefits. We explore the consequences, for older women, of eliminating the RET from the Full Retirement Age to age 69 (in 2000), relying on the inter-cohort variation in exposure to changes in the RET to estimate these effects. The evidence is consistent with the conclusion that eliminating the RET increased the likelihood of having very low incomes among women in their mid-70s and older - ages at which the lower benefits from claiming earlier could outweigh higher income in the earlier period when women or their husbands increased their labor supply.

Theodore Figinski

U.S. Department of the Treasury 1500 Pennsylvania Avenue, NW

Washington, D.C. 20220

Theodore.Figinski@treasury.gov

David Neumark

Department of Economics

University of California at Irvine

3151 Social Science Plaza

Irvine, CA 92697

and NBER

dneumark@uci.edu 


\section{Introduction}

The Social Security retirement earnings test (RET) establishes a threshold for which earnings in excess of the threshold cause a reduction in benefits. Prior to 2000, the RET reduced benefits by $\$ 1$ for every \$3 earned above the threshold, for beneficiaries from the Full Retirement Age (FRA, then 65) to age 69 (Social Security Administration, 2010). Beneficiaries age 62 to the FRA are subject to a more restrictive RET, reducing benefits by $\$ 1$ for every $\$ 2$ earned above the threshold, with a lower threshold. The Senior Citizens’ Freedom to Work Act of 2000 repealed the RET for beneficiaries who had attained the FRA (as well as making the RET less stringent in the year an individual reached the FRA). There were earlier reforms of the RET in the 1980s.

The RET is viewed as a tax (Liebman and Luttmer, 2011), despite the fact that the lost benefits are provided in the future. As a result, the predicted effect of the removal of the RET on labor supply (and hence earnings) depends on where the beneficiary was on the budget constraint prior to the elimination of the RET (Haider and Loughran, 2008). Figure 1 provides the budget constraints with and without the RET. Beneficiaries choosing low hours prior to 2000 (locating on segment DC in Figure 1) should be unaffected by the elimination of the RET. Among those affected, beneficiaries whose labor supply led to the elimination of all their Social Security benefits (locating on segment BE in Figure 1) experience an income effect, hence likely decreasing their hours worked. Those bunching just at or below the RET threshold (point D in Figure 1) should increase their hours worked through the substitution effect. ${ }^{1}$ And for those receiving reduced benefits due to earning above the threshold (locating on segment DE), there is both an income and a substitution effect, so the net effect is ambiguous.

Thus, the average effect of the 2000 removal on beneficiaries' labor supply decision and earnings is unclear from the theoretical predictions. But earlier research on either primary beneficiaries or only men finds bunching of earnings just below levels where the RET applies (Friedberg, 2000; Gruber and Orszag, 2003; Song and Manchester, 2007; Haider and Loughran, 2008), and net increases in labor supply and earnings from eliminating the threshold. Recent work focused on the 2000 reforms studies female primary

\footnotetext{
${ }^{1}$ Gelber et al. (2015) provide evidence of such bunching (and that when the RET was removed this bunching was slow to dissipate, consistent with costs of adjusting labor supply/earnings).
} 
and spousal beneficiaries (Figinski, 2013), and finds that, like men, female primary beneficiaries affected by the removal of the RET increased their labor supply and earnings, although there was no change for spousal beneficiaries. $^{2}$

Concomitant with changes in labor supply, however, are effects on benefit claiming and hence on benefit levels. Men or women working enough to be subject to the RET have an incentive to delay claiming, and conversely to claim earlier when the RET is eliminated or reduced, resulting in lower monthly Social Security benefits. In particular, with the 2000 policy changes, there should be some people who move the age of claiming benefits from above the FRA down to the FRA, because the RET was eliminated for those attaining the FRA. Looking at reforms in the 1980s, Gruber and Orszag (2003) find this for men, and Figinski (2013) also finds that women - both primary and spousal beneficiaries - claimed benefits earlier when the RET was eliminated in 2000, for certain age groups. (See also Song and Manchester, 2007.) Those who claim benefits early and continue to work will be able to supplement their wage income with Social Security benefits. Yet these individuals may not save for the time when they can no longer work and thus, especially when they stop working, may have lower incomes - including Social Security payments - than if they had not claimed benefits earlier in response to the elimination of the RET. As explained below, this problem may be particularly severe for older women.

As a consequence of these responses, removing the RET could have the unintended effect of increasing poverty - or the incidence of low-income more generally - among much older individuals. Gruber and Orszag (2003) were the first to point this out, suggesting that the removal of the RET for younger beneficiaries “could produce a non-trivial increase in elderly poverty” (p. 771). Of course there is a potential offsetting response, if the elimination of the RET implies that people work longer and therefore run down their assets more slowly, with positive implications for resources available at older ages.

It is this potential for longer-term response of changes in the RET that we explore in this research. We know from past work (e.g., Sandell and Iams, 1997) that old-age poverty is common among women,

\footnotetext{
${ }^{2}$ The absence of a labor supply response among female spousal beneficiaries could reflect low skills, or careers where it is difficult to re-enter the labor market or increase earnings, as well as an income effect in response to husband's higher earnings stemming from removal of the RET
} 
beginning around age 75. Smeeding and Sandstrom (2005) and Gornick et al. (2009) discuss the persistent problem of poverty among older women who live alone, pointing to very high incidence of low incomes in the United States (and providing comparisons with other high-income countries). In the United States, this problem may stem in part from how Social Security benefits change with early claiming, such that women, who generally outlive men, will face actuarially unfair benefit reductions from early claiming (by them or their husbands) - a problem that is exacerbated by the structure of spousal and survivor benefits (Sass et al., 2007). ${ }^{3}$

We focus on women, in particular, because they generally outlive men. Hence, women - and especially older women - are more likely to reach the point where reliance on Social Security benefits is higher. In this case, the lower benefits from claiming earlier are more likely to outweigh the higher earnings or saving from increased labor supply in response to the elimination of the RET.

Although the research, of necessity, looks backwards at responses to past changes in the RET, it has potential implications for the future, if policymakers were to eliminate or further reduce the RET at age 62 in an effort to encourage more work beyond age 62. The positive labor supply response of female primary beneficiaries, coupled with the results from the previous literature showing labor supply increases of men and primary beneficiaries (regardless of sex), may suggest that, as the FRA rises further (beginning with the 1955 birth cohort), the RET should be removed for all beneficiaries. ${ }^{4}$ Yet as the FRA increases further, individuals who claim benefits at age 62 will receive a greater reduction in benefits for claiming benefits early. For those who claim benefits early and do not continue to work, the lower benefit level will make it more difficult to make ends meet. Those who claim benefits early and continue to work will have both earned income and Social Security benefits. But these individuals may not save for the time when they can no longer work and become dependent on Social Security payments for their income. Thus, creating incentives to work more by eliminating the RET - because it also increases incentives to claim benefits at an earlier age - may increase poverty, or the incidence of low-income more generally, among older individuals,

\footnotetext{
${ }^{3}$ For example, husbands who are much older than their wives may not take account of the increase in the value of survivors' benefits for their wives from delayed claiming.

${ }^{4}$ See, e.g., https://www.govtrack.us/congress/bills/113/hr174/summary (viewed April 6, 2016).
} 
and especially older women.

\section{Past Research}

The earnings increases that Figinski (2013) finds for male and female primary beneficiaries are similar - around 19-20 percent. If people claim benefits one year earlier, the benefit reduction is generally 6.7 percent. ${ }^{5}$ But the latter effect persists for every year after benefits are claimed. Thus, it seems unlikely that extra earnings of 19-20 percent for perhaps a year or two would be nearly enough to offset the benefit reduction, even if we were just considering a surviving (female) spouse with lower costs of living. There is the potential for higher benefits for some because of benefit re-computation replacing higher earnings with lower earnings, although that is likely only for certain occupations for which the earnings profile implies favorable re-computation.

Song and Manchester (2007) find that the effect on earnings of removing the RET at the FRA is concentrated among high earners (for both males, and for female primary beneficiaries), suggesting that there may be little effect on those more likely to be poor at old ages. But the elimination of the RET could still encourage earlier benefit claiming among those with lower incomes, for those whose earnings prior to the change exceed the earnings test threshold, and hence were not claiming benefits, but who have little ability to increase or manipulate their earnings in response to changes in the RET. In contrast, if low earners simply are unlikely to have earnings after age 65, then we would not expect much claiming response for them.

\section{Empirical Approach}

The fundamental goal of the empirical analysis is to test whether the 2000 reforms eliminating the RET had adverse consequences for the incomes of much older women whose own behavior or spouse's behavior was affected by the elimination of the RET. The challenge in estimating this kind of effect is the usual one of the counterfactual. We would like to compare observed outcomes for cohorts affected by the elimination of the RET to what their outcomes would have been had the RET not changed. An inherent difficulty of this approach in studying the elimination of the RET, however, is that the policy change applies to everyone in the affected cohort. Thus, identification is less compelling than in a case with, for example,

\footnotetext{
${ }^{5}$ For cohorts born in 1938 and after, it is slightly more complicated, with a smaller reduction in benefits for benefits claimed more than three years before the FRA; see Neumark and Song (2013).
} 
geographic policy variation so that only some members of particular cohorts are affected.

We estimate reduced-form models in which we identify the effect of the elimination of the RET from inter-cohort changes. To keep things simple, consider first a world without couples, in which women in different cohorts face different RET rules, choose when to claim benefits in part based on these rules, and then for whom we subsequently observe Social Security benefits and other sources of income. The corresponding reduced-form equation for age at claiming, for example, is of the form:

$$
\operatorname{AgeClaim}_{i}^{w}=\alpha+\beta E E T_{i}^{w}+X_{i}^{w} \gamma+\varepsilon_{i},
$$

where AgeClaimw ${ }^{w}$ is the age of the woman/wife when she claimed Social Security benefits, $E E T^{w}$ is a dummy variable equal to one for cohorts of women for which the RET from the FRA through age 69 was eliminated, and $X^{w}$ is a vector of demographic control variables (race/ethnicity, educational attainment, and marital status). $X^{w}$ also includes a dummy variable for cohorts reaching age 65 in 2003 or later, for which the FRA was greater than 65 and benefits before the FRA were lower than for earlier cohorts. ${ }^{6}$ We also estimate versions of this model in which $E E T^{w}$ is broken up into five dummy variables for those aged 69 in 2000, aged 68, aged 67, aged 66, and aged 65 or younger. The youngest group had the highest "exposure” to the elimination of the RET, whereas the oldest group was exposed only at age 69, and hence should have changed its behavior less.

This regression identifies the effects of the elimination of the RET from differences in outcomes between cohorts that were and were not affected by the elimination of the RET. It is estimated for subsamples of women aged 70 or older, all of whom should have claimed their Social Security benefits, albeit at ages that may differ because of exposure to the elimination of the RET. If we had policy variation across states then we could identify the policy effects from interactions at the ages and cohorts affected by the policy change in the states where the policy change occurs, with the unaffected cohorts controlling for other cohort-specific changes. ${ }^{7}$ Identification of the effect of the elimination of the RET in equation (1)

\footnotetext{
${ }^{6}$ These individuals would be predicted to claim benefits later and have lower benefits conditional on age (see Neumark and Song, 2013).

${ }^{7}$ By way of contrast, for example, Krueger and Pischke's (1992) paper on the "notch babies" (born 1917-1921) who faced much lower Social benefits than either immediately older or immediately younger cohorts, which allows the researchers to infer the effect of lower benefits on labor supply by looking for a break in the longer-term time-series behavior of labor supply for this narrow cohort (which turns out to be weak). Snyder and Evans (2006) present a
} 
requires the identifying assumption that there are not other sources of differences in these outcomes across cohorts. One could imagine introducing some function of year of birth and including this as a control to allow for other sources of change by birth cohort. However, because the actual effect of the elimination of the RET is to introduce variation in years of exposure to the elimination of the RET that goes from one for those aged 69 in 2000, to five for those aged 65 or younger in 2000, it can be difficult to distinguish between the effects of the elimination of the RET by cohort and other cohort effects. We provide evidence on whether the effect we estimate is real by asking whether the changes correspond to what we would expect if the crosscohort changes are driving by changes in the RET. As one approach, we compare results for a wider and narrower range of birth cohorts, to ensure that the results are generated from the affected cohorts; with the narrower range, it is less likely that other sources of cross-cohort differences are important. We can also learn something from the estimates of the specification in which $E E T^{w}$ is broken up into five dummy variables that capture differences in the number of years and youngest age of "exposure” to the elimination of the RET. The effect should be stronger the younger an individual was at the time of the elimination of the RET because there was more time to adjust behavior; that is, if the effect is causal then there is an expected "doseresponse” function reflecting at least this general behavior. Finally, we show descriptive graphs that permit the reader to form their own impression of how compelling the evidence is that the elimination of the RET is largely responsible for the effects we estimate. Nonetheless, there is no denying the fact that simply using cohort variation might be viewed as not entirely compelling, although for reasons discussed above it is the best we can do this in this case.

We estimate this model for age at claiming as explained above, to establish a baseline for our analysis and to touch base with the earlier literature. In particular, we expect those exposed to the elimination of the RET to claim benefits earlier. We are more interested, however, in the consequences for income - and more specifically the incidence of low income. We therefore also estimate similar specifications for Social

similar analysis of the effect of the benefits change on mortality (and also report higher post-retirement labor supply for the affected cohorts). And closest to this paper, Disney and Smith (2002) study the effect of the elimination of the earnings test in the United Kingdom. However, they look only at employment, and hence can do difference-indifferences estimation between those younger than and older than the affected ages, using the younger group as a control. Because we focus on claiming Social Security benefits and the value of those benefits, the younger group is not usable as a control. (Moreover, it is not entirely clear the younger group's behavior would not be affected by the policy change.) 
Security benefits, and then for income below thresholds that are multiples of the poverty line.

The indexation of Social Security benefits has implications for how to construct the counterfactual benefits used in equation (1) when we study benefits or all income. To be concrete, consider the example of using data only on the 1931 and 1930 birth cohorts; because these cohorts are aged 69 and 70, respectively, in 2000, the first is affected by the elimination of the RET, and the second is not affected. Because of the change in the policy, members of the 1931 birth cohort would be expected, on average, to claim benefits earlier, resulting in lower benefits. The reduced-form regression uses unaffected cohorts - in this example, the 1930 birth cohort - as a counterfactual for what benefits would have been (and when they would have been claimed) - for the 1931 birth cohort.

For the age at claiming, there is no inherent problem. As long as we assume there were no other cohort effects aside from the elimination of the RET that would have led to different ages at claiming across these cohorts - which is the key identifying assumption - the estimate of $\beta$ identifies the cohort effect.

However, when the outcome is benefits, getting the counterfactual right is more complicated. As in the analysis of the effect on the age at claiming, we want to use outcomes for the 1930 cohort as the counterfactual. But the indexation of Social Security benefits implies that benefits for the 1930 cohort may not correctly estimate the counterfactual for the 1931 cohort had the RET not been eliminated. In particular, there is a two-step indexation process. First, for each individual, the average wage index (AWI) as of age 60 is used to bring earnings prior to age 60 up to current nominal levels in setting the primary insurance amount (PIA) based on the average indexed monthly earnings (AIME). In our two cohort example, this means that the PIA of the older 1930 birth cohort would have to be inflated by the AWI for 1991 relative to 1990 to get the right "counterfactual PIA” for the 1931 birth cohort. This is important because otherwise the benefits of the 1931 birth cohort may appear too high - masking the reduction in benefits from claiming earlier because of the elimination of the RET. The PIA is subsequently indexed by the CPI-W, which implies that we have to use this index from age 60 to the year of observation to have comparable current dollar benefits for the two cohorts. $^{8}$

\footnotetext{
${ }^{8}$ For more on indexation of Social Security benefits, see http://www.ssa.gov/oact/cola/AWI.html,
} 
Thus, when we look at Social Security benefits, we first multiply by the ratio of the AWI in 1995 to the AWI when the person was age 60. The year 1995 is chosen somewhat arbitrarily, but this means that we put all workers' benefits on an equivalent footing, in terms of the AWI, to a worker who was age 65 in 2000 (the first cohort exposed to the elimination of the RET beginning at the FRA). Then, because benefits are observed at different years depending on age and when a person is observed in the Health and Retirement Study (HRS), we multiply this adjusted figure by the ratio of the CPI-W in 2013 to the CPI-W in 1995, to express all benefits in 2013 dollars. Benefits can still vary across individuals (and couples) based on when they claimed benefits - which affects the relationship between PIA and benefits. But by doing this indexation, we isolate the variation in benefits due to age at claiming.

In general, we cannot simply use the values of the AWI in the different years people turned 60 to equate the values of their AIMEs if they had different earnings streams. However, this adjustment does isolate the role of the AWI for workers with otherwise identical earnings streams, which is all we want to do to construct the counterfactual. To see this, Table 1 presents a simple example, in which there are workers in two different, successive cohorts, each of whom works for three years (using the last year as the analogy to age 60). They have identical nominal earnings streams ( $Y 1, Y 2, Y 3)$ except for the difference reflected in the AWI $(W(t))$. In this case, adjusting the AIME of the younger worker for indexation by the AWI requires only the ratio $W(4) / W(3)$, or, more generally, the AIME for each cohort at age 60 . To see this, note that given the earnings streams in Table 1, using the AWI to construct the AIME for each worker yields:

AIME worker 1 , retiring in year 3 , in year 3

$$
=Y 3+Y 2 \cdot(W(3) / W(2)+Y 1 \cdot(W(3) / W(1))
$$

and

AIME worker 2, retiring in year 4 , in year 4

$=Y 3 \cdot(W(4) / W(3))+Y 2 \cdot(W(3) / W(2)) \cdot(W(4) / W(3))+Y 1 \cdot(W(2) / W(1)) \cdot(W(4) / W(2))$

$=Y 3 \cdot(W(4) / W(3))+Y 2 \cdot(W(4) / W(2))+Y 1 \cdot(W(4) / W(1))$

Note, though, that equating the two earnings streams then just requires multiplying the last expression in equation (2) by $W(3) / W(4)$, which is equivalent more generally in our case to multiplying by 
the ratio of the AWI in 1995 to the AWI when the person was age 60. (If the person turned 60 after 1995, this ratio will be less than one, and if the person turned 60 before 1995, this ratio will exceed one.)

For our main analysis of the effects of the elimination of the RET on poverty or low-income, we have to construct total income across Social Security benefits and other sources. For non-Social Security income, we simply index by the CPI-U to express all amounts in 2013 dollars (since the same counterfactual issue arising from wage indexing of benefits does not arise). But we still use benefits indexed as described in the previous paragraph.

The indexing of Social Security benefits by the AWI, however, has important implications for the measurement of poverty and hence for estimating the effects of eliminating the RET on the incidence of low income relative to the poverty line. In particular, the AWI generally rises faster than the CPI, reflecting growth in real wages. Given that the poverty threshold in the United States is an absolute rather than a relative measure, one can view the indexation of Social Security benefits by the AWI as building into the system a long-term reduction in poverty as successive generations get benefits that reflect the real wage growth their birth cohort experienced. This implies, though, that when we index Social Security benefits as described above to construct our counterfactual - applying the AWI for younger cohorts to older cohorts the implied poverty rate for samples of older women will be lower than actually observed. As a result, when we estimate the effect of eliminating the RET on old-age poverty, we use an adjusted poverty measure that preserves the observed poverty rate, by adjusting the poverty threshold for each sample so that the poverty rate based on indexed benefits and other income is identical to the observed poverty rate absent the counterfactual adjustment. (That is, for observed poverty rate $p$ in any sample we study, we define the $p^{\text {th }}$ percentile of the indexed income distribution as the adjusted poverty threshold.) Note that the implication of this adjustment is that, ceteris paribus, the counterfactual poverty rate for an older cohort were it instead born later, and hence benefited from the higher AWI for younger cohorts, is always lower - which we interpret as exactly the purpose of using the AWI in setting Social Security benefits.

To this point we have described models that are estimated for women only. We also, however, estimate models that capture the effects of the elimination of the RET for both women and their husbands, since both can affect benefits (depending on whether the woman is claiming her own benefits or 
spousal/survivor benefits).

The reduced-form equation incorporating the exposure of both husbands and wives to the elimination of the RET is simple, and takes the form:

$\operatorname{AgeClaim}_{i}^{w}=\alpha+\beta E E T_{i}^{w}+\beta^{\prime} E E T_{i}^{h}+X_{i}^{w} \gamma+\varepsilon_{i}$.

$E E T^{h}$ is the dummy variable indicating that the husband was younger than age 70 in $2000 .^{9}$

\section{Data}

To study the effects of the elimination of the RET, we use the Health and Retirement Study (HRS). ${ }^{10}$ The HRS is a longitudinal survey administered every two years, interviewing a nationally representative sample of individuals older than age 50. The HRS began collecting data in 1992 and the most recent available data in the HRS is from the 2012 survey wave.

We impose several sample restrictions on the data to obtain the final samples. We begin by limiting the HRS data to individuals whose Social Security claiming age is not missing and is between ages 62 and 71. We remove observations that report receiving annual Social Security benefits less than $\$ 6,000$ or greater than $\$ 35,500 .{ }^{11}$ Finally, for most of the analyses presenting our main results, we limit our data to women in two age ranges. Our “age 70+ sample” consists of women ages 70 and 71, and our "age 75+ sample” consists of women ages 75 and 76. We use a two-year window because the HRS is conducted every two years. The age of the individual is measured at the end of the reference year, typically the calendar year prior to the interview year. ${ }^{12}$ This results in a sample of 2,974 women in the age 70+ sample and 1,958 women in the age 75+ sample. The first four columns of Table 2 contain the number of observations by age in these two samples, and by whether the person's birth cohort made them less than age 70 in 2000 and hence subject to the elimination of the RET, and older than 70. Later, we report on the robustness of our key conclusions especially changes in the results as women age - to looking at a much broader range of ages.

We also create subsamples that include only women who can be matched to a unique husband;

\footnotetext{
${ }^{9}$ We also estimated some versions of this specification where we included two sets of five dummy variables - one for the woman and one for her husband - indicating one, two, three, four, or five years of exposure to the elimination of the RET.

${ }^{10}$ We use the RAND version of the HRS.

11 These limits are imposed based on the CPI-U inflation adjusted Social Security benefits to 2013 dollars.

${ }^{12}$ For the HRS income questions, the reference year is typically the calendar year prior to the interview year.
} 
observations that report multiple husbands complicate matters because it is unclear which husband's age and hence exposure to the elimination of the RET - affects the woman's Social Security benefits. We use these subsamples to study the effects of the husband's claiming decision on the family's and wife's outcomes. To construct this sample, we removed women from the sample who never report a spouse or report multiple spouses during the HRS sample. ${ }^{13}$ We also limit this sample to women whose husband's Social Security claiming age is not missing and is between ages 62 and 71. The corresponding sample sizes by age and cohort are also reported in Table 2 (last four columns).

One of the primary outcomes of interest is whether or not a woman's income is below particular lowincome thresholds, such as the poverty line or a multiple of it. Unfortunately, the HRS does not provide a measure of whether household income is below the poverty line or a multiple of it until the 2002 wave. For data prior to 2002, we construct measures of poverty (or income below thresholds based on the poverty line) using the Census Bureau's definition of poverty. To determine whether the household has income below the poverty line or other thresholds, the Census Bureau uses the number of individuals residing in the household, the total income of the members of the household, and the age of the related children residing in the household. The HRS only includes the total income of the respondent and spouse (if one is present) in its measure of household income. To obtain the age of the related children, we merge in the RAND HRS family data (which includes information on the number of children residing with the respondent from 1992 to 2008). However, in line with the earlier discussion of the correct construction of Social Security benefits for the counterfactual, we use a constructed income measure, which is whether adjusted benefits (as described earlier) plus other household income is below the poverty line or a multiple of it. ${ }^{14}$

Descriptive statistics are reported in Table 3. These reflect features we would expect. For example,

${ }^{13}$ In implementing this method, we require women to be observed as "married" at least once during the HRS sample. We also exclude same-sex couples because all of the data occurs before the U.S. Supreme Court's decision in United States $v$. Windsor in 2013, which allowed same-sex married couples to claim on their spouse's work history in the same manner as heterosexual married couples do.

${ }^{14}$ In order to check how accurate our calculated low-income measures are at predicting the incidence of poverty or low income, we apply our measure to the entire HRS sample for the 2002 to 2008 waves and compare the incidence of poverty to the HRS calculated poverty measure. (Observations with a zero weight are excluded to avoid including observations residing in nursing homes.) The calculated measure is able to accurately predict whether or not the household resides in poverty in 96 percent of cases, and whether or not the household is below 200 percent of the poverty line in 93 percent of cases. (This calculation is done without our adjustment of benefits by the AWI.) Note that our key results for older women (e.g., the age 75+ sample), are not affected by this imputation because all observations come from 2002 or later. 
the average age at claiming benefits (self-reported) is between 63 and 64. The widowhood rate is much higher for the all women sample than for the women with husband's sample, regardless of age. While the sample of women for whom we observe a husband during the sample period has a lower widowhood rate than women overall, the probability of being widowed in this sample dramatically increases between age 70 and 75 (from 0.17 to 0.27 ).

One thing to note in Table 3 is the much lower incidence of poverty (or being below other lowincome thresholds) in the samples of women with unique husbands observed, in the last two columns although, as expected, these percentages of women living below low-income thresholds increase sharply between the ages of 70 and 75 . The sample of women with unique husbands has a much lower incidence of low income because they were married at some point in the period covered by the HRS, and also because if they were divorced they have not had multiple husbands in the period covered by the HRS. ${ }^{15}$

As a consequence of the very low share of women in the sample of women with unique husbands observed who are below the poverty line, we focus our analysis on whether women are below 150 percent or 200 percent of the poverty line. The proportions living below these thresholds are higher, as Table 3 shows, likely in part because the sample selection necessary to define the treatment of husbands is not as severe for this threshold. These thresholds are still of considerable interest because they would still be considered to be low-income thresholds. In addition, the results may differ for these somewhat higher income thresholds, because - as Figure 1 shows - those with higher earnings initially are more likely to increase labor supply in response to the elimination of the RET. That is, at these thresholds we may be somewhat less likely to see older women affected by the elimination of the RET having very low incomes; the fact that we, nonetheless, find such an effect for these above-poverty thresholds, thus strengthens our conclusions.

Our analysis uses the public HRS data, in which we cannot identify what kind of benefits women are claiming. ${ }^{16}$ Ideally, we would also (or instead) use the confidential administrative Social Security records

\footnotetext{
${ }^{15}$ For example, the unadjusted poverty rates for the women we drop to obtain our women with husbands sample at age 70 are as follows: 11 percent live below the poverty line, 25.5 percent live below 150 percent of the poverty line, and 38.6 percent live below 200 percent of the poverty line. At age 75, the unadjusted poverty rates for these individuals are as follows: 12.7 percent live below the poverty line, 31.8 percent live below 150 percent of the poverty line, and 46.7 percent live below 200 percent of the poverty line.

${ }^{16}$ Appendix Table A1 gives information on the type of benefits women earned over the 1995-2013 period. In addition
} 
that are available for many HRS respondents, which would give us an administrative measure of the age at claiming, and also identify what kind of benefits women are claiming and thus perhaps better pin down whose exposure to the elimination of the RET (a woman's or her husband's) are driving benefits. ${ }^{17}$

However, the administrative data are complicated, and our work with these data has identified two issues pointing to problems with identifying the relevant claiming date in the administrative data. First, there are substantial discrepancies between self-reported age at claiming and the age at claiming calculated using the administrative data. ${ }^{18}$ The number of discrepancies is large, and many are four months or larger or even 13 months are larger. There is a difference between cohorts born before 1931 - for whom claiming dates are almost always based on recall before the first survey for the relevant cohort - and those born in 1931 or later - for whom claiming dates come from recall limited to the two years between interviews and should be more accurate. ${ }^{19}$ The errors are larger for those born before 1931, as we might expect. But there are many large errors for the younger cohorts as well. The difference across birth cohorts is particularly problematic because birth year 1931 is the dividing line between those who are or are not affected by the elimination of the RET.

We could of course assume the administrative data are correct. But this leads to the second issue. Specifically, when we try to replicate the Song and Manchester (2007) results using the HRS administrative data, we are unable to replicate their findings. Yet, when we use the HRS public data and the self-reported age at claiming, we are able to replicate the Song and Manchester (2007) findings. This is reported in Appendix Table A3.

To create a sample similar to Song and Manchester (2007), we limit the administrative data to men

to showing the percentage of women claiming on their own work histories, Table A1 displays the fraction claiming "spousal" or "survivor" benefits. Spousal benefits are equal to one-half the husband's benefit amount. When the husband dies, the wife can choose to continue her current benefits (either own or spousal) or claim survivor benefits, which are equal to the husband's benefit. Typically, the highest benefit amount is claimed. While men can claim either spousal or survivor benefits, it is typically women who receive these benefit types. Table A1 shows a substantial share of women are receiving benefits based on their own earnings histories, especially in more recent years.

17 Even for a woman claiming her own benefits her age at claiming may be affected by her husband's decision and hence his exposure to the elimination of the RET - for example because of leisure complementarities. For work on this topic see Hurd (1990) and Coile (2004). For a more recent study using French data see Stancanelli and van Soest (2012).

18 See Appendix Table A2.

19 The HRS cohort was born 1931-1941 (although spouses can be born in different years), and was first interviewed in 1992. The AHEAD and CODA cohorts were born earlier, but not interviewed until later (first in 1993 for the AHEAD cohort, and 1998 for the CODA cohort). Thus, claiming dates for those born before 1931 are generally recalled. 
and women who are observed claiming benefits and who have not claimed disability benefits. In the public data, we limit the sample to individuals who report a claiming age of age 62 or older to avoid including individuals who are receiving disability benefits. Song and Manchester (2007) conduct the analysis for two treatment groups. One of the treatment groups includes those who had attained ages 65 to 69 by January 1 of the calendar year. The second treatment group includes those who turn age 65 during the year. We focus on replicating the estimates for the first group because the RET is completely eliminated for these individuals. While the estimates for those turning age 65 during the calendar year are informative, these individuals face a pro-rated RET during the months prior to turning age $65 .{ }^{20}$ In contrast, the RET is completely eliminated for those who have reached age 65 prior to January 1 of the calendar year.

Appendix Table A3 provides our estimates using the HRS administrative and public sample. Using the HRS public data we find statistically significant increases in claiming for the treatment group that are in line with the Song and Manchester (2007) findings. Using the HRS administrative data, however, we find small and statistically insignificant changes in claiming behavior for the treatment group. Together, these findings lead us to proceed using the public HRS data. ${ }^{21}$

\section{Results}

\section{Individual Benefits}

We begin with models estimated for Social Security benefits and the age at claiming, to test for the expected effects (in some cases reflected in earlier literature as well) that the RET leads to earlier claiming and lower benefits. As a precursor, Figure 2 reports the average age at claiming by birth year for the narrower birth cohort range (women born between 1925 and 1940). The first vertical line in the figure shows the oldest and youngest cohorts affected by the elimination of the RET, from left (1930) to right (1935). The oldest cohort was only exposed beginning at age 69 (under age 70 when the policy change occurred), and this fell to age 65 for the 1935 cohort - where it remained for all subsequent cohorts. Thus, if age at claiming were driven only by changes in the RET, we would expect age at claiming to begin to decline for the 1930

\footnotetext{
${ }^{20}$ Note this assumes that the FRA is age 65. The same is true for FRAs above age 65. In the year the individual reaches the FRA, the individual faces a pro-rated earnings test during the months prior to reaching the FRA.

${ }^{21}$ The administrative Song and Manchester replication sample and the public-use Song and Manchester replication sample are very similar with regard to age, race, and marital status.
} 
birth cohort, to decline relatively more for the subsequent birth cohorts out to 1935, and then to stabilize. The figure does show a sharp decline beginning with the 1931 birth cohort, and age at claiming stays low. The figure does not suggest that there is no variation other than that driven by the elimination of the RET, with a dose-response function indicating a clear increased response for each affected birth cohort from 1930 to 1935. But the figure does qualitatively fit this story.

In Table 4, we report OLS estimates, for women in isolation, of regressions for the age at claiming benefits (for the cohorts covered in Figure 2, and a broader range). The specifications vary in two ways: first, whether we include a single dummy variable for "exposure" to the elimination of the RET (less than age 70 in 2000), or instead five dummy variables that capture the age at which the elimination of the RET occurred; and second, whether we use the full sample, or a more restricted range of birth cohorts. As columns (1) and (3) of Table 4 show, for both samples we find that the elimination of the RET reduces the age at claiming by about 8 to 9 months - estimates that are statistically significant at the one-percent level. In columns (2) and (4), where we instead use the richer characterization of exposure to elimination of the RET, we find, for the most part, that the younger the woman was when the RET was eliminated, the earlier she claimed. The estimates range from 6.5 to 7.8 months for those who were 69 when the RET was eliminated, to about 8.2 to 9.6 months for those who were aged 65 or less. The expected dose-response of earlier claiming for the younger cohorts who were the most affected is partially evident, but not every estimate fits this pattern. This partly monotonic relationship suggests that we are not picking up spurious cohort effects unrelated to the elimination of the RET, although a clearer monotonic relationship would be more assuring. We also note that the estimated effects do seem large, if, especially the older affected cohorts, only those who have not claimed benefits by age 65 are affected by the elimination of the RET; it is possible, though, that some claiming prior to age 65 is also affected, perhaps because of the forward-looking and/or joint nature of decisions regarding claiming and labor supply.

We next turn to the analysis of benefits. We again begin with a figure depicting the raw data - Figure 
3. To be sure, the data are quite noisy. ${ }^{22}$ However, there is a detectable pattern of benefits declining as the RET was eliminated, and being lowest for the cohorts born 1935 or after that experienced the elimination of the RET beginning at age 65 .

The regression estimates (for the cohorts covered in Figure 3, and a broader range) are reported in Table 5. The estimates reflect what we would expect based on the results for age at claiming, as well as what we saw in Figure 3. In columns (1) and (3), we see that benefits (annual) are lower by about $\$ 650-\$ 800$ for cohorts for whom the RET was eliminated. In columns (2) and (4), the expected dose-response of lower benefits for the younger cohorts who were the most affected is partially but not fully evident. The big exception is for some anomalous results for those aged 66 in 2000, corresponding to the spike for the 1934 birth cohort in Figure 3). However, the estimate for the cohorts aged 65 or younger in 2000 (born 1935 or later) are the largest (negative). Some of the inconsistent dose-response relationships for other cohorts may reflect imprecise estimates for small cell sizes for single-year birth cohorts. In contrast, we get the most observations on those who were 65 or younger in 2000, reflected in considerably lower standard errors.

\section{Family Benefits}

Having established these results for women in isolation, we next turn to the effects of the elimination of the RET on poverty or low-income status of older women. In this case, we estimate specifications for family Social Security benefits and income relative to poverty. The approach parallels the above analysis for women only, except that we now study a sample of women with one husband observed during the period covered by our HRS data so that we can determine the birth cohort of the husband that would have determined his exposure to the elimination of the RET. ${ }^{23}$ In addition, we estimate models including variables capturing both the wife's and the husband's exposure to the elimination of the RET.

We begin with the analysis of the age at claiming Social Security benefits. First, again for the

\footnotetext{
${ }^{22}$ We considered using the administrative data on Social Security benefits available for many HRS records, but given the difficulties encountered in trying to use age at claiming in these data, we thought it preferable to do all the analysis with a consistent data set.

${ }^{23}$ Note that the subsample of women we use is smaller because of this restriction. In results not reported in this paper, we verified that the results for this subsample, but looking only at women's benefits, estimating the same specifications as in Tables 4 and 5, qualitatively replicated the results for the larger sample of women covered in those tables, although the estimated effects on benefits were a bit smaller and less often statistically significant. On the other hand, these results sometimes better matched the expected dose-response relationships with years of exposure to the elimination of the RET.
} 
narrower cohort range, Panel A of Figure 4 reports the average age at claiming by birth year for women (wives). More so than in Figure 2, this figure clearly shows a sharp decline in age at claiming beginning with the 1931 birth cohort, and age at claiming remains low. There is not a prominent dose-response function except for the first couple of affected cohorts. Panel B shows the same results for men (husbands). In this case, there is a clear downward trend, and no obvious break with the elimination of the RET. That does not mean there was not an effect, but this evidence for men highlights the identification issue we raised earlier that inferring an effect from cross-cohort changes can be problematic when there are pre-treatment changes. This paper focuses to a large extent on women, and emphasizes the sample in which we do not necessarily see women matched to a unique husband, so the problematic evidence in Panel B of Figure 4 does not underlie all of our results. Nonetheless, the evidence suggests some caution in interpreting our results on the incidence of low income, since income is defined at the family level.

Table 6, columns (1)-(4), turns to the regression estimates for age at claiming. From this point, we report results only for the (slightly) narrower birth cohort range of 1925 through 1940; results were similar for the 1918-1942 range for which we reported results in Tables 4 and 5. We report estimates for both women and their husbands, using the single treatment effect for each (e.g., for women, "Less than age 70 in 2000”), and then five separate dummy variables for each breaking out the age at which the RET was first eliminated. Columns (1) and (2) report results for wives’ age at claiming, and columns (3) and (4) for husbands' age at claiming. In columns (1) and (3) we see, not surprisingly, that the wife's age at claiming is affected by whether she was less than age 70 in 2000, and the husband's age at claiming by his age in 2000. Both estimates are negative and statistically significant at the one-percent level, indicating earlier claiming among those for whom the RET was eliminated. There is no evidence of "cross" effects between spouses. In columns (2) and (4) we see evidence of the expected dose-response function, with the effect rising the younger the age at which one was exposed. The estimate is nearly monotonic for wives; it is not quite so clean for husbands, but the two largest effects are for those aged 66, or aged 65 and younger, with the latter, as expected, the larger of the two.

Column (5) of Table 6 turns to evidence on family Social Security benefits, again taking account of both husbands' and wives' exposure to the elimination of the RET. However, recall our earlier caveat that 
these results are based on a highly selected sample of women with a unique husband observed in the HRS. We find fairly strong evidence that when husbands were exposed to the elimination of the RET, family benefits are lower. Conditional on the exposure of husbands, the effects are the opposite sign for women's exposure. This finding is a bit puzzling, and may reflect other influences on benefit levels associated with whether the wife was less than age 70 in 2000, conditional on whether the husband also was less than age 70 in 2000. Another way to think about the estimates, though, is that both spouses are likely to be affected similarly by the policy, given small age differences between most husbands and wives. Alternatively, the “experiment” of thinking about the partial effect of eliminating the RET only for wives, or only for husbands, is of limited interest and potentially hard to interpret - more a reflection of the age gap between husbands and wives than of the policy change. In this case, the fact that the effects for husbands are larger indicates that, on net, family benefits are likely to be lowered somewhat because of the elimination of the RET. Indeed, this is shown in the last row of the table, where we report the combined effect of eliminating the RET for both husbands and wives, leading to significantly lower annual benefits of around \$1,500. Given the perspective that the separate effects for husbands and wives may be less meaningful than the combined effects, the dose-response relationship is harder to characterize, and hence we do not report such specifications. $^{24}$

\section{The Incidence of Low Income Relative to Poverty}

Finally, we turn to estimated effects on the incidence of low-income as defined by multiples of the poverty threshold. For reasons discussed earlier, we focus on the thresholds set at 150 and 200 percent of the poverty line in our regression analysis, although our figures also include data for the poverty line (100 percent) threshold. Panel A of Figure 5 shows the share below each threshold by birth cohort for the sample of all women first observed at 70 or older, for whom we have already seen evidence of earlier claiming and lower benefits from the elimination of the RET. For the 100-percent threshold, there is no clear pattern of an increase in poverty, whereas for the higher thresholds it appears that the share with incomes below those thresholds is a bit lower for cohorts more affected by the elimination of the RET, although the evidence is far

\footnotetext{
${ }^{24}$ And for the same reason, the types of figures discussed earlier are less meaningful.
} 
from clear. Panel B shows the same kind of information, but for an older sample of women first observed at age 75 or older - when women are likely to depend more exclusively on Social Security benefits, and hence for whom we might be more apt to see the emergence of adverse effects of the elimination of the RET on family income. (For example, as reported in Table 3, for the sample of women for whom we observe a husband, Social Security benefits make up 59.5 percent of total household income at age 70 and 68.6 percent of total household income at age 75.) In Panel B there is, indeed, more evidence of an uptick in the incidence of low income, and more so for the 150- and 200-percent thresholds. Moreover, many of the graphs in Figure 5 are suggestive of the expected dose-response relationship, with the incidence of low-income rising for cohorts affected by the elimination of the RET at a younger age.

Table 7 reports the regression results for these latter two thresholds. ${ }^{25}$ Columns (1)-(4) report results for the sample of all women, and columns (5) and (6) for the women with husbands observed. The top panel reports results for the sample of first observations on women aged at least 70, and the bottom panel for women aged at least 75. Looking first at the all women sample first observed aged at least 70, for the simpler specifications in columns (1) and (3), the estimates indicate that exposure of women to the elimination of the RET is associated with a lower probability of living below either 150 or 200 percent of the poverty line. Both estimates are significant at the 10-percent level, and indicate that this probability is lower by about 2.4 to 3.3 percentage points.

Interestingly, however, in the bottom panel that turns to the older sample of women first observed at age 75 or older, the results are reversed. Women's exposure to the elimination of the RET is now associated with a higher probability of living below either 150 or 200 percent of the poverty line - by 2.7 to 3.7 percentage points, also statistically significant at the 10-percent level. The differences in the results for the older sample relative to the sample first observed at age 70 suggest that as women move into their mid-70s, the effect of lower Social Security benefits from early claiming may come to dominate the effects of higher earnings (and whatever effect those higher earnings had on income from savings).

Columns (2) and (4) provide evidence on the dose-response relationship with regard to the age at

\footnotetext{
${ }^{25}$ For all of the income-threshold analyses, we report linear probability estimates, but verified that the results we report are similar using probit models.
} 
which the RET was eliminated. For the sample first observed aged at least 70, in Panel A, the expected relationship is not clear for the 150-percent threshold, but for the 200-percent threshold, although not monotonic, the effects are largest for the women exposed relatively longer. In Panel B, for the older sample, the effect is always largest (and only statistically significant) for the women exposed the longest; this evidence is also reflected in Figure 5.

Finally, in columns (5) and (6) we turn to the sample of women with husbands observed, and include the effects of husbands' exposure to the elimination of the RET as well. In Panel A, for the sample of women first observed at age 70 or older, the estimated effects of women's exposure to the elimination of the RET is weaker, although still negative (as in columns (1) and (3)). For the 150-percent threshold, there is a positive estimated effects of husbands' exposure on the incidence of low income. Earlier, though, we argued that the combined effects are of greatest interest, and the last row of Panel A indicates small and insignificant effects. In Panel B, for the older sample of women, the estimated effect of women's exposure to the elimination of the RET is always positive, and significant (at the 10-percent level or better). The estimated effect is 0.036 for the 150-percent threshold, and nearly twice that for the 200-percent threshold. The estimated effects of husbands' exposure to the elimination of the RET are near zero, so the summed effects are similar to the estimated effects for women alone. Again, the differences relative to the results for the sample first observed at age 70 or older suggest that, as women age into their mid-70s, the effect of lower Social Security benefits from early claiming comes to dominate the effects of higher earnings (and whatever effect those higher earnings had on income from saving). ${ }^{26}$

We have interpreted the differences between the age 70+ and age 75+ samples as indicating that the effect of the elimination of the RET in generating low family incomes emerges at older ages for women, when the effects of lower benefits are more likely to outweigh additional labor income. To gauge whether this is a plausible interpretation, rather than simply a difference that emerges for these two specific age

\footnotetext{
${ }^{26}$ One might view as contradictory the evidence in Table 6 that family benefits are negatively affected by the husband's exposure to the elimination of the RET, and the evidence in Table 7 that higher poverty (for the older sample) is driven by the wife's exposure. However, there can be both claiming/benefit and labor supply responses, and greater effects on income than on benefits of women's exposure to the elimination of the RET may be explained by less of a labor supply response for them than for husbands, resulting in lower income by the ages at which the labor supply response has dissipated.
} 
thresholds, Figure 6 reports results for a much wider range of age cutoffs, for both samples of women. In these graphs, the estimates for ages 70-71 and 75-76 correspond to those reported in the tables (columns (1), (3), (5), and (6) of Table 7). The other estimates come from estimating the exact same specifications, but for the age ranges shown in the figures. What we see in the figures is that, in general, as women age over this range there is a rising likelihood of having income below either the 150-percent or 200percent threshold (relative to poverty). And clearly the rising positive effect on the incidence of low-income as women age is not an idiosyncratic finding that occurs only for the comparison between the 70-71 and 7576 year-old samples. We interpret these figures as providing additional evidence that as women reach quite old ages, adverse effects of the elimination of the RET on their incomes emerge.

\section{Conclusion}

The elimination of the RET for those between the FRA and age 69, in 2000, was intended to boost employment of those in this age range who might be deterred from working because of the reduction in Social Security benefits owing to the RET. At the same time, the elimination of the RET makes those who are working more likely to claim early. Thus, this policy change is expected to increase earnings in the shortrun, but reduce Social Security benefits in the longer-run, and possibly also influence the time-path of retirement assets, saving, and income from those assets, with uncertain effects on family income (including benefits) at older ages - perhaps in particular older women who are likely to outlive their spouses, and likely

to reach the point where any extra labor income from the positive work incentives of eliminating the RET are no longer evident. Finding out whether this change in the RET increased the incidence of low income for older women is important not only for understanding the effects of the 2000 policy change, but also the potential effects of additional efforts to encourage work by eliminating or reducing the RET between age 62 and the FRA, which currently reduces benefits by $\$ 1$ for every $\$ 2$ of earnings.

Our findings support a few conclusions. First, we confirm past findings that the elimination of the RET led to earlier claiming of benefits for women. Second, coupling this evidence with other evidence that men also claim benefits earlier, Social Security benefits at the individual and family level are generally lower as a result of the elimination of the RET. Third, the results for poverty and low-income status tend to fit the conjecture about a lower incidence of low income initially - when women are at or just above age 70 - but a 
higher incidence of low income as women get into their mid-70s and beyond. These findings suggest that the incidence of low income among old women was increased by the elimination of the RET.

At the same time, we caution that the evidence should be viewed as suggestive, because identification comes from cross-cohort differences, rather than the kind of quasi-experiment that is often preferred in policy analysis because of the greater scope for controlling for other changes across cohorts. In the absence of such a quasi-experiment, we discuss the extent to which there is evidence of the expected dose-response - with younger cohorts exposed to the elimination of the RET at younger ages exhibiting stronger changes in behavior. There is indeed some evidence of these kinds of responses for most of the outcomes we study, although perhaps not as clear and consistent as to be completely compelling. On the other hand, forward-looking or joint husband-wife responses to the RET might dilute the expected doseresponse relationship.

This type of analysis could be extended in ways that may yield additional insight, including: examination of labor income, saving, and other sources of income that might be affected by the elimination of the RET; identification of the role of widowhood, which increases substantially after age $70 ;{ }^{27}$ and identification of individuals and families more likely to be affected in one direction or the other by the elimination of the RET from the FRA through age 69, which may provide more useful information on the expected effects of eliminating or reducing the RET for those between 62 and the FRA, which may be more likely to affect behavior of those who are lower-skilled and have lower past earnings.

\footnotetext{
27 The percentages widowed in our "married” sample are 16.6 percent at age 70 and 26.5 percent at age 75 (see Table $3)$. For the "all women" samples, the percentages are 25.5 percent at age 70 and 38.2 percent at age 75 .
} 


\section{References}

Coile, Courtney. 2004. “Retirement Incentives and Couples’ Retirement Decisions.” The B.E. Journal of Economic Analysis \& Policy 4 (1), 1-30.

Disney, Richard, and Sarah Smith. 2002. "The Labour Supply Effect of the Abolition of the Earnings Rule for Older Workers in the United Kingdom.” Economic Journal 112 (478), C136-C152.

Figinski, Theodore F. 2013. “Women and the Social Security Earnings Test.” Unpublished manuscript.

Friedberg, Leora, 2000. “The Labor Supply Effects of the Social Security Earnings Test.” Review of Economics and Statistics 82 (1), 429-450.

Gelber, Alexander M., Damon Jones, and Daniel W. Sacks. 2015. “Earnings Adjustment Frictions: Evidence from the Social Security Earnings Test.” Unpublished manuscript.

Gornick, Janet C., Teresa Munzi, Eva Sierminska, and Timothy M. Smeeding. 2009. "Income, Assets, and Poverty: Older Women in Comparative Perspective.” Journal of Women, Politics \& Policy 30 (2-3), 272-300.

Gruber, Jonathan, and Peter Orszag. 2003. "Does the Social Security Earnings Test Affect Labor Supply and Benefit Receipt?” National Tax Journal 56 (4), 755-773.

Haider, Steven J., and David S. Loughran. 2008. "The Effect of the Social Security Earnings Test on Male Labor Supply: New Evidence from Survey and Administrative Data.” Journal of Human Resources 43 (1), 56-87.

Hurd, Michael D. 1990. “The Joint Retirement Decision of Husbands and Wives.” In David A. Wise, ed., Issues in the Economics of Aging. Chicago: University of Chicago Press, 231-258.

Krueger, Alan, and Jörn Steffen Pischke. 1992. "The Effect of Social Security on Labor Supply: A Cohort Analysis of the Notch Generation.” Journal of Labor Economics 10 (4), 412-437.

Liebman, Jeffrey B., and Erzo F.P. Luttmer. 2011. "Would People Behave Differently if They Better Understood Social Security? Evidence from a Field Experiment.” NBER Working Paper 17287.

Neumark, David, and Joanne Song. 2013. “Do Stronger Age Discrimination Laws Make Social Security Reforms More Effective?” Journal of Public Economics 108, 1-16.

Sandell, Steven H., and Howard M. Iams. 1997. "Reducing Women’s Poverty by Shifting Social Security Benefits from Retired Couples to Widows.” Journal of Policy Analysis and Management 16 (2), 279297.

Sass, Steven A., Wei Sun, and Anthony Web. 2007. "Why Do Married Men Claim Social Security Benefits So Early? Ignorance or Caddishness?” Boston College Center for Retirement Research Working Paper.

Smeeding, Timothy M., and Susanna Sandstrom. 2005. "Poverty and Income Maintenance in Old Age: A Cross-National View of Low Income Older Women.” Feminist Economics 11 (1), 163-197.

Snyder, Stephen E., and William N. Evans. 2006. "The Effect of Income on Mortality: Evidence from the Social Security Notch.” Review of Economics and Statistics 88 (3), 482-495.

Social Security Administration. 2010. Annual Statistical Supplement to the Social Security Bulletin, 2009. Social Security Administration, Washington, D.C.

Song, Jae G., and Joyce M. Manchester. 2007. "New Evidence on Earnings and Benefit Claims Following Changes in the Retirement Earnings Test in 2000.” Journal of Public Economics 91 (3-4), 669-700.

Stancanelli, Elena G.F., and Arthur van Soest. 2012. "Joint Leisure Before and After Retirement: A Double Regression Discontinuity Approach.” IZA Discussion Paper No. 6698. 
Figure 1: Budget Constraint

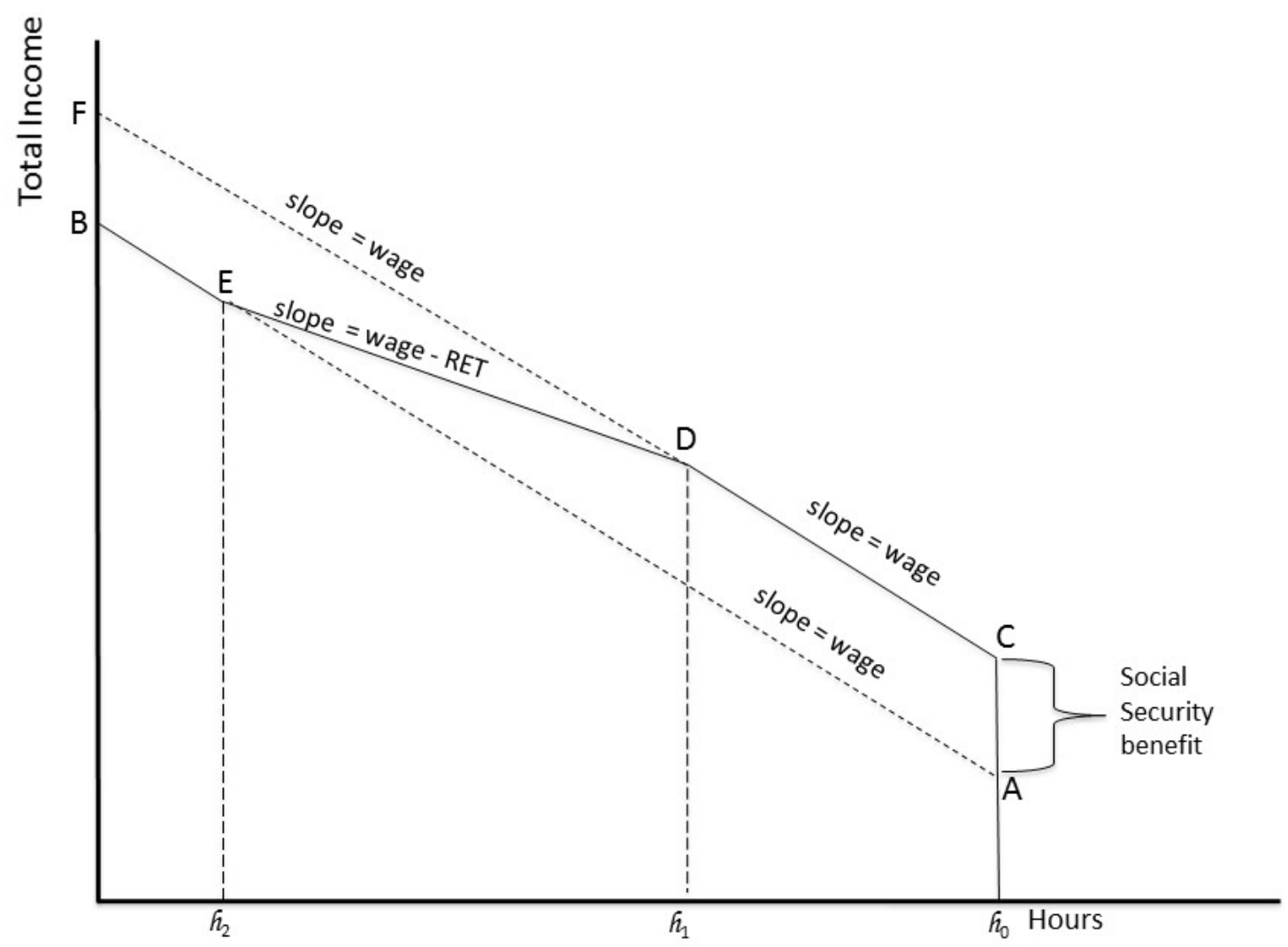

Notes: Prior to the 2000 removal of the retirement earnings test (RET), all Social Security beneficiaries younger than age 70 faced a budget constraint of CDEB. If beneficiaries younger than age 70 chose to work past the threshold (point D), these beneficiaries received a reduction in benefits (ET). After the 2000 elimination of the RET, beneficiaries who had attained the Full Retirement Age (FRA) faced a budget constraint of CDF (ignoring other taxes and benefits). Beneficiaries age 62 to the FRA continue to face a budget constraint like CDEB even after the 2000 changes. 
Figure 2: Average Age at Claiming by Birth Year, All Women Sample, at Age 70, Born between 1925 and 1940

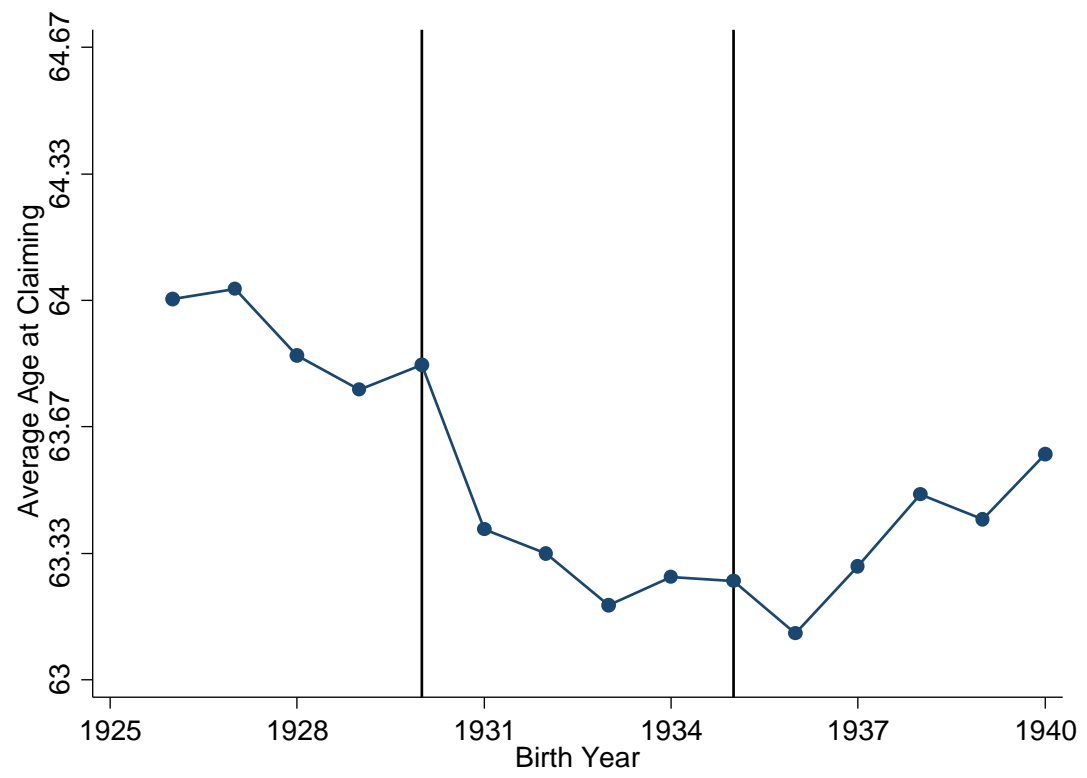

Notes: Cells with fewer than 50 observations are suppressed. The first vertical line indicates those born in 1930, who were age 70 in 2000 and unaffected by the elimination of the RET. The second vertical line indicates those born in 1935, who were age 65 in 2000 and were exposed to five years of the elimination of the RET.

Figure 3: Average Social Security Benefits (AWI/CPI-U Adjusted) by Birth Year, at Age 70, All Women Sample, Born between 1925 and 1940

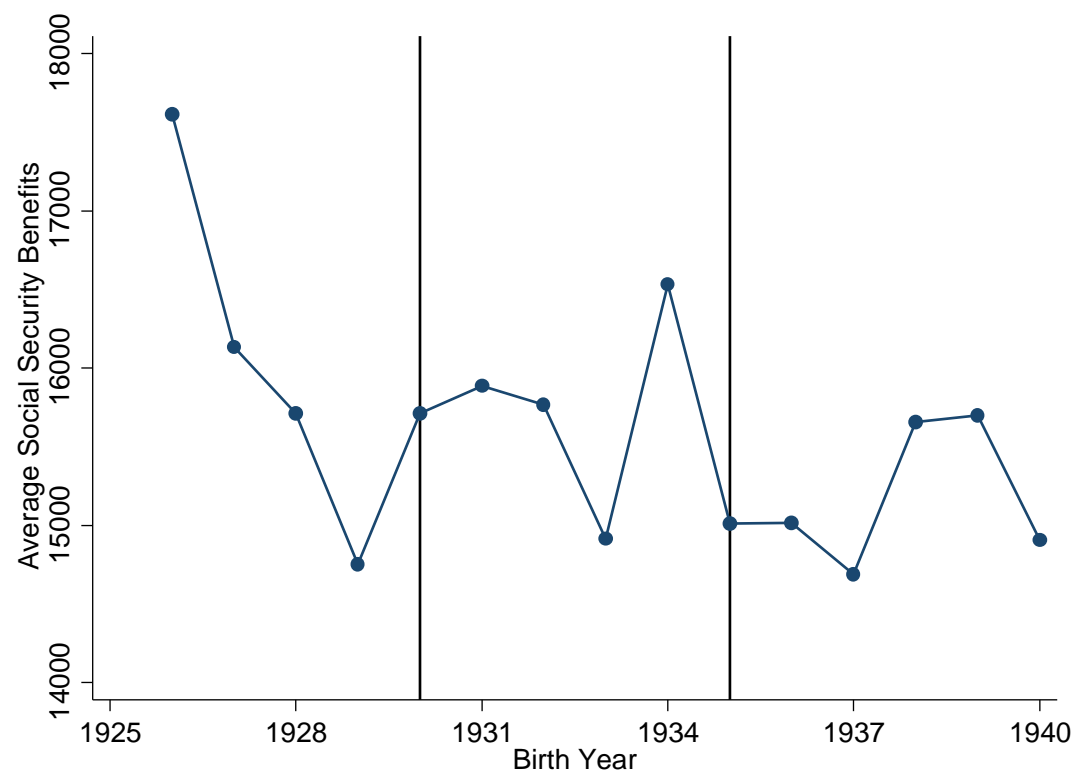

Notes: See notes to Figure 2. 
Figure 4: Average Age at Claiming by Birth Year, Women with Husbands Sample, at Age 70, Born between 1925 and 1940

A. Wives

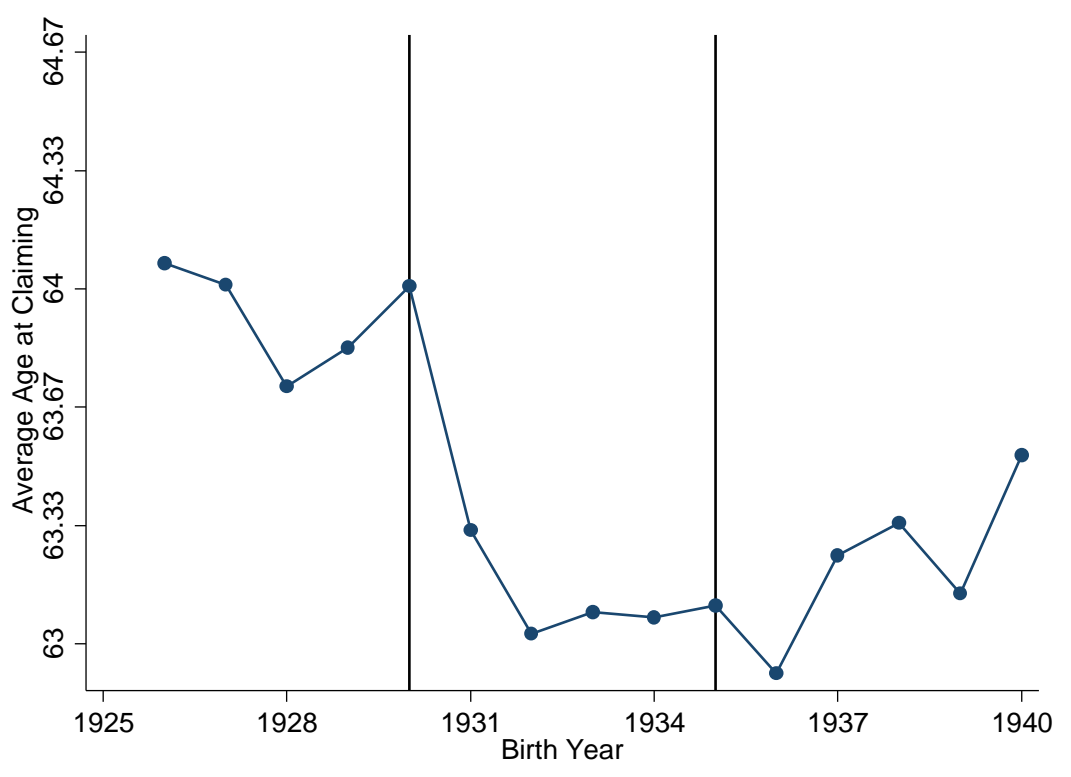

B. Husbands

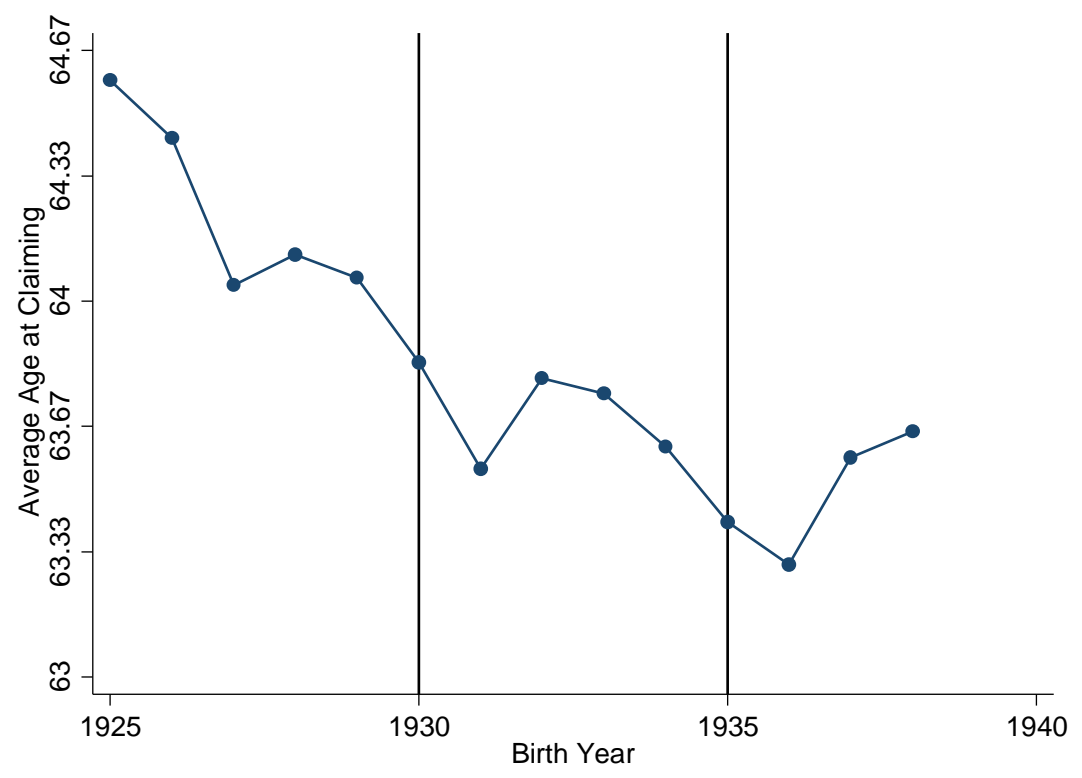

Notes: See notes to Figure 2. 
Figure 5: (Adjusted) Poverty/Low-Income Rates by Birth Year, All Women Sample, at Ages 70 and 75, Born between 1925 and 1940

A. Women first observed age 70 or older

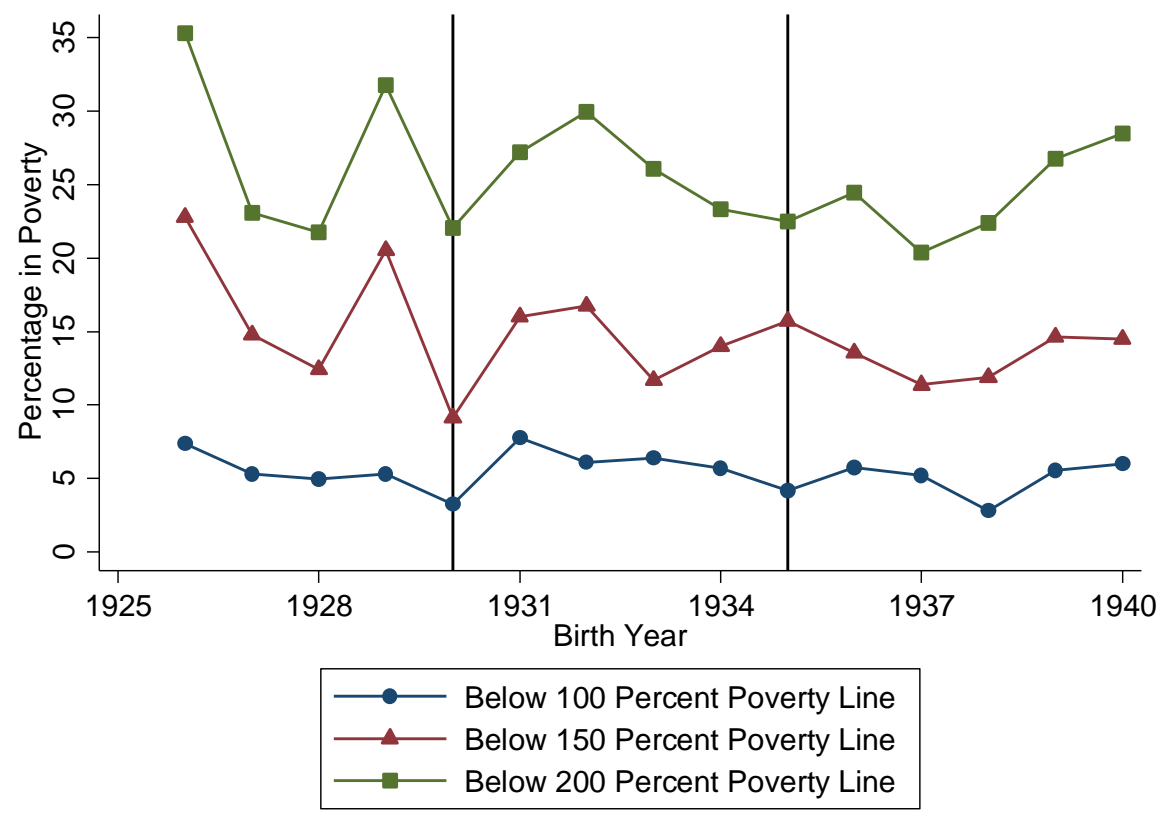

B. Women first observed age 75 or older
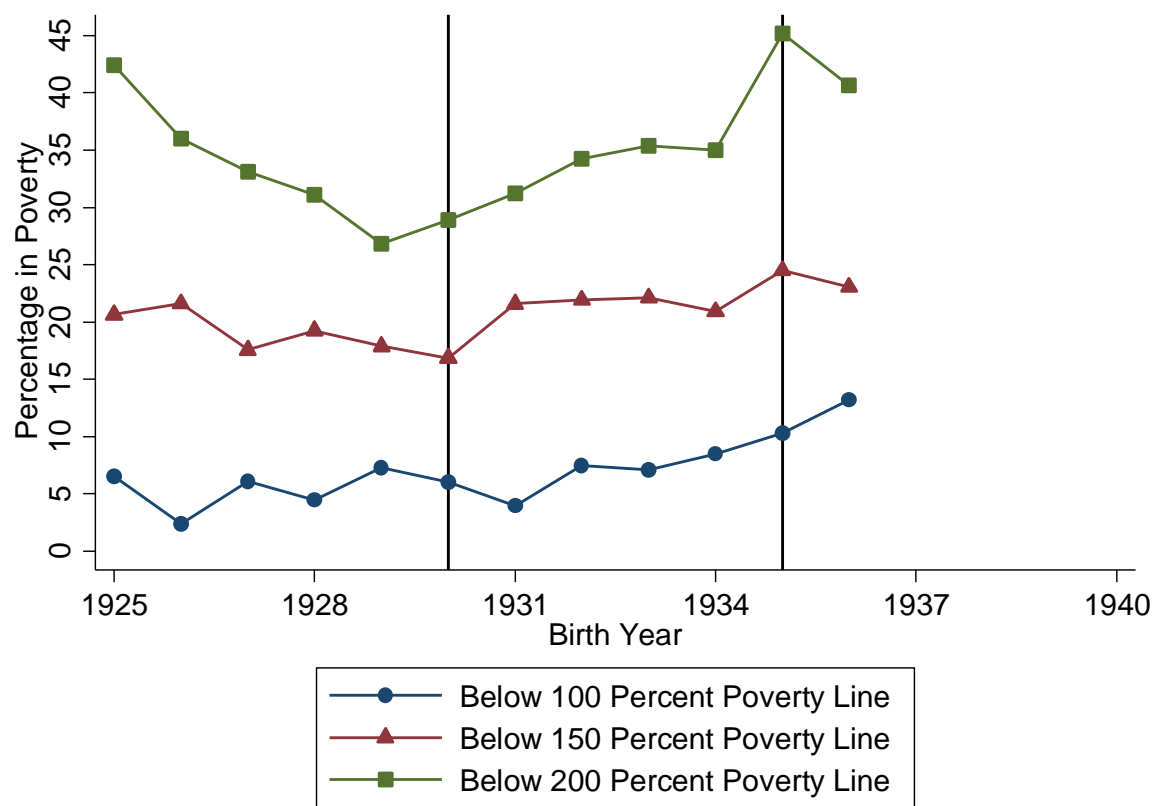

Notes: See notes to Figure 2. 
Figure 6: Results on the Incidence of Low Income Relative to Poverty, Additional Ages, All Women

A. 150 Percent of the Poverty Line, All Women

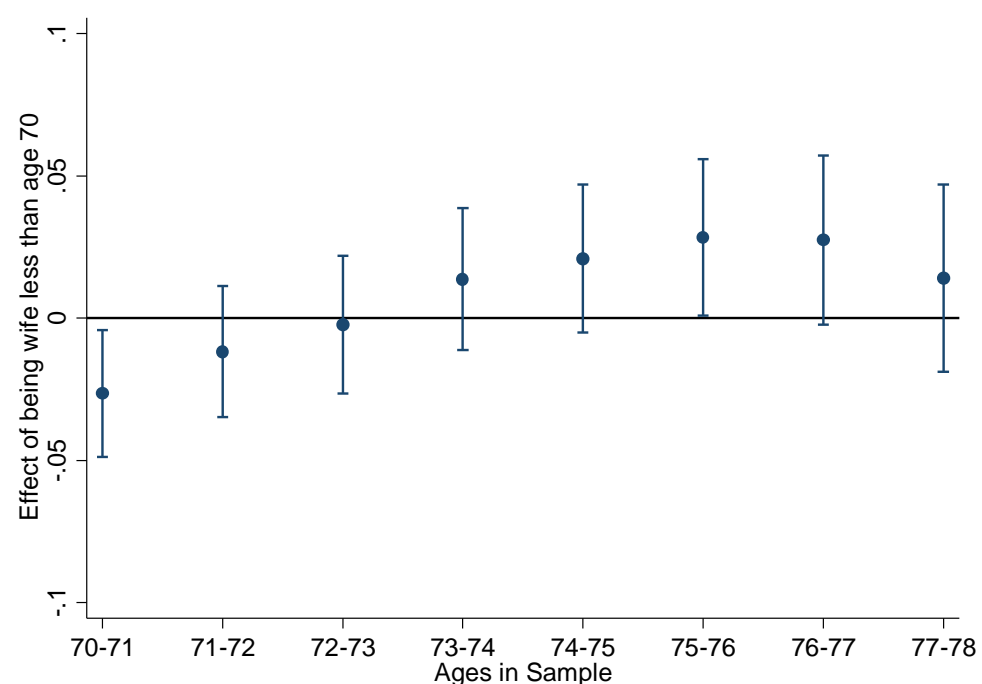

C. 150 Percent of the Poverty Line, Women with Husband Observed

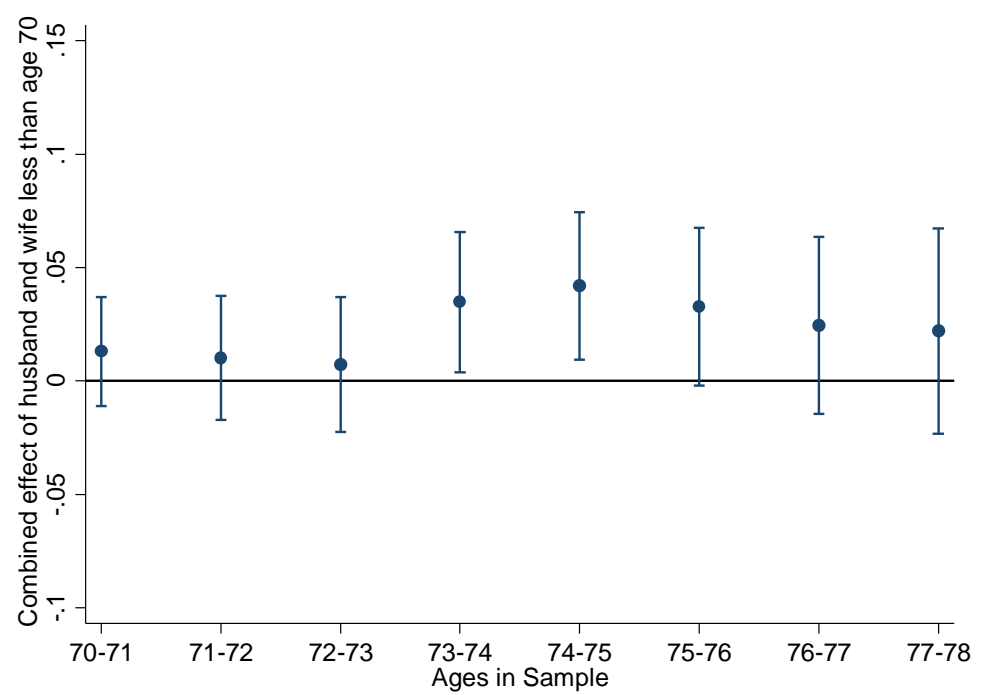

B. 200 Percent of the Poverty Line, All Women

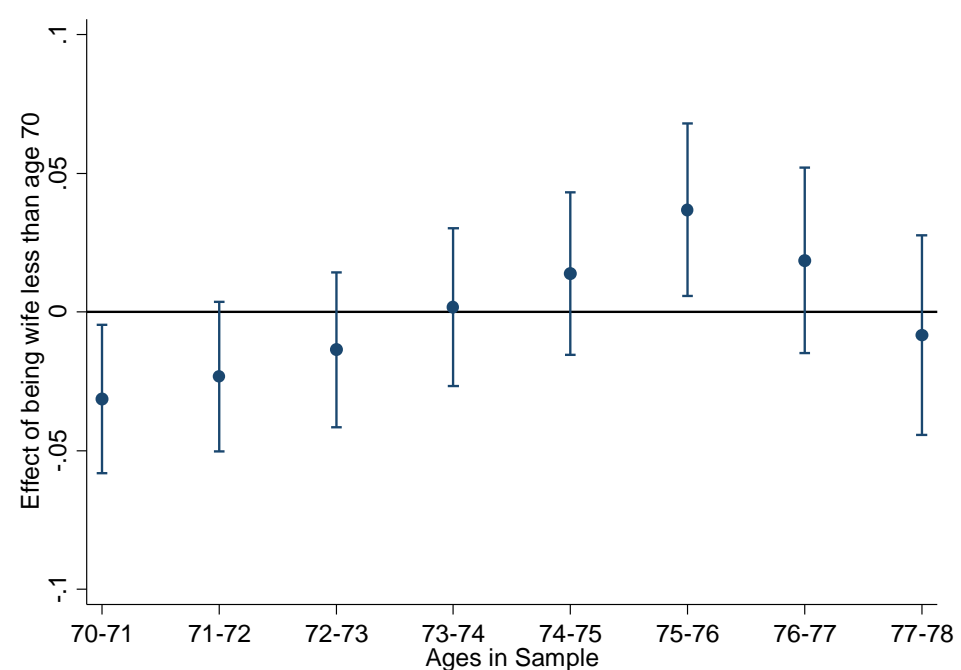

D. 200 Percent of the Poverty Line, Women with Husband Observed

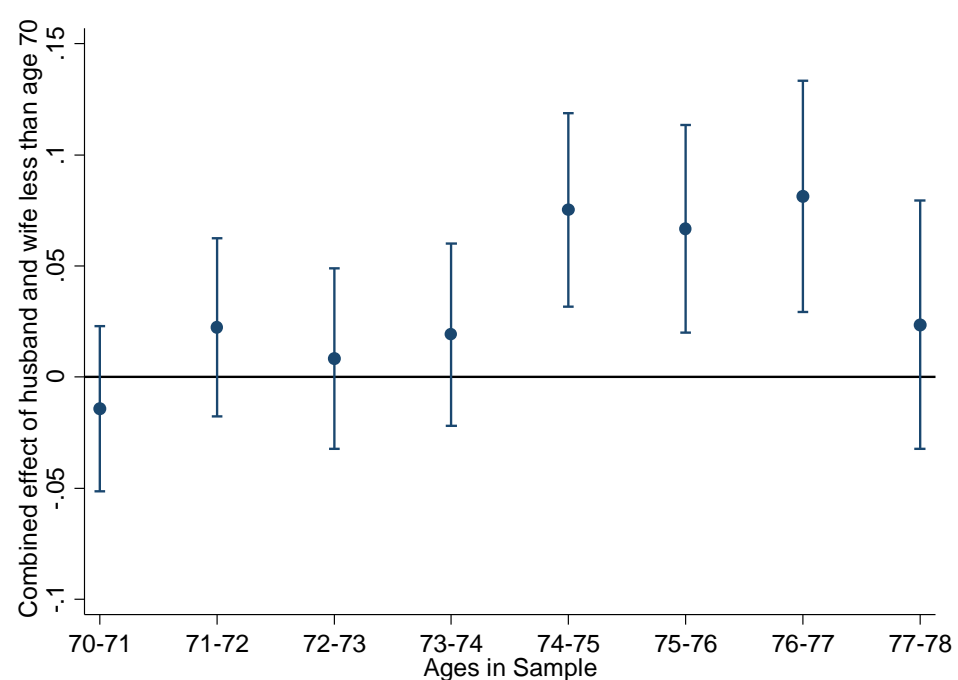

Notes: 90 percent confidence intervals are shown. Only results for those born between 1925 and 1940 are shown. The results graphed for ages 70-71 and 75-76 in the top row correspond to the estimates in Panels A and B, columns (1) and (2), of Table 7, and those in the bottom row correspond to columns (5) and (6) in Table 7. 
Table 1: Hypothetical Adjustment of Earnings Streams by AWI for Workers in Successive Cohorts

\begin{tabular}{|c|c|c|c|c|}
\hline & Year 1 & Year 2 & Year 3 & Year 4 \\
\hline Worker 1 earnings & $Y 1$ & $Y 2$ & $Y 3$ & \\
\hline Worker 2 earnings & & $Y 1 \cdot(W(2) / W(1))$ & $Y 2 \cdot(W(3) / W(2))$ & $\mathrm{Y} 3 \cdot(W(4) / W(3))$ \\
\hline AWI & $W(1)$ & $W(2)$ & $W(3)$ & $W(4)$ \\
\hline
\end{tabular}

Notes: Worker 2's earnings stream is identical except for the nominal growth captured by the index $W(t), t$

$=1,2,3,4$.

Table 2: Number of Observations in Each Sample by Age and Birth Cohort

\begin{tabular}{|c|c|c|c|c|c|c|c|c|}
\hline \multirow[b]{3}{*}{ Age } & \multicolumn{4}{|c|}{ Women } & \multicolumn{4}{|c|}{ Women with husbands } \\
\hline & \multicolumn{2}{|c|}{ Age $70+$ sample } & \multicolumn{2}{|c|}{ Age $75+$ sample } & \multicolumn{2}{|c|}{ Age $70+$ sample } & \multicolumn{2}{|c|}{ Age $75+$ sample } \\
\hline & $\begin{array}{l}\text { Less than age } \\
70 \text { in } 2000 \\
\end{array}$ & $\begin{array}{c}\text { Age } 70 \text { or } \\
\text { older in } 2000\end{array}$ & $\begin{array}{l}\text { Less than age } \\
70 \text { in } 2000 \\
\end{array}$ & $\begin{array}{c}\text { Age } 70 \text { or } \\
\text { older in } 2000\end{array}$ & $\begin{array}{l}\text { Less than age } \\
70 \text { in } 2000 \\
\end{array}$ & $\begin{array}{c}\text { Age } 70 \text { or } \\
\text { older in } 2000\end{array}$ & $\begin{array}{l}\text { Less than age } \\
70 \text { in } 2000 \\
\end{array}$ & $\begin{array}{c}\text { Age } 70 \text { or } \\
\text { older in } 2000\end{array}$ \\
\hline & $(1)$ & $(2)$ & (3) & $(4)$ & (5) & $(6)$ & $(7)$ & $(8)$ \\
\hline 70 & 336 & 1,187 & & & 166 & 661 & & \\
\hline 71 & 509 & 942 & & & 248 & 564 & & \\
\hline 75 & & & 543 & 542 & & & 256 & 345 \\
\hline 76 & & & 406 & 467 & & & 188 & 274 \\
\hline Total & 845 & 2,129 & 949 & 1,009 & 414 & 1,225 & 444 & 619 \\
\hline
\end{tabular}

Notes: The sample is limited to individuals who are currently claiming Social Security benefits, who report Social Security benefits of greater than $\$ 6,000$ but less than \$35,500 in 2013 dollars, and who report an age at claiming of between ages of 62 and 71. For the "Women with husbands" sample, we further limit the sample by removing women who never report a spouse or report multiple spouses during the HRS sample, and requiring that husband's Social Security claiming age is not missing and is between ages 62 and 71.

Source: Data from the RAND Health and Retirement Study from the 1992 to 2012 waves. 
Table 3: Descriptive Statistics for Different Samples

\begin{tabular}{|c|c|c|c|c|}
\hline \multirow[b]{2}{*}{ Variable } & \multicolumn{2}{|c|}{ All women } & \multicolumn{2}{|c|}{$\begin{array}{l}\text { Women with husbands } \\
\text { observed }\end{array}$} \\
\hline & $\begin{array}{c}\text { Age } 70+ \\
\text { sample }\end{array}$ & $\begin{array}{c}\text { Age } 75+ \\
\text { sample }\end{array}$ & $\begin{array}{c}\text { Age } 70+ \\
\text { sample }\end{array}$ & $\begin{array}{r}\text { Age } 75+ \\
\text { sample }\end{array}$ \\
\hline & $(1)$ & $(2)$ & (3) & $(4)$ \\
\hline $\begin{array}{l}\text { Individual annual Social Security } \\
\text { benefits, adjusted }\end{array}$ & 15,547 & 19,142 & 14,480 & 17,885 \\
\hline $\begin{array}{l}\text { Family annual Social Security benefits, } \\
\text { adjusted }\end{array}$ & .. & .. & 33,259 & 37,419 \\
\hline \multicolumn{5}{|l|}{ Share below poverty line } \\
\hline Unadjusted & 0.0588 & 0.0728 & 0.0172 & 0.0276 \\
\hline OASI Benefits Adjusted & 0.0588 & 0.0728 & 0.0172 & 0.0276 \\
\hline \multicolumn{5}{|l|}{ Share below $150 \%$ of poverty line } \\
\hline Unadjusted & 0.1500 & 0.2060 & 0.0646 & 0.1120 \\
\hline OASI Benefits Adjusted & 0.1500 & 0.2060 & 0.0646 & 0.1120 \\
\hline \multicolumn{5}{|l|}{ Share below $200 \%$ of poverty line } \\
\hline Unadjusted & 0.2620 & 0.3460 & 0.1620 & 0.2460 \\
\hline OASI Benefits Adjusted & 0.2620 & 0.3460 & 0.1620 & 0.2460 \\
\hline $\begin{array}{l}\text { Family income excluding Social } \\
\text { Security benefits }\end{array}$ & $\ldots$ & $\ldots$ & 48,772 & 40,125 \\
\hline $\begin{array}{l}\text { Social Security benefits (adjusted) as } \\
\text { share of family income }\end{array}$ & $\cdots$ & .. & 0.595 & 0.686 \\
\hline Age & 70.94 & 75.89 & 70.95 & 75.88 \\
\hline Age at claiming & 63.54 & 63.67 & 63.39 & 63.45 \\
\hline Median Year of Birth & 1934 & 1931 & 1934 & 1931 \\
\hline$<$ High school & 0.196 & 0.207 & 0.154 & 0.163 \\
\hline High school grad or GED & 0.428 & 0.423 & 0.464 & 0.451 \\
\hline Some college & 0.225 & 0.228 & 0.228 & 0.234 \\
\hline College degree (BA) or higher & 0.151 & 0.142 & 0.155 & 0.152 \\
\hline White & 0.845 & 0.854 & 0.906 & 0.908 \\
\hline Black & 0.123 & 0.115 & 0.066 & 0.068 \\
\hline Other & 0.033 & 0.031 & 0.028 & 0.025 \\
\hline Current marital status: married & 0.556 & 0.468 & 0.818 & 0.721 \\
\hline Current marital status: partnered & 0.016 & 0.012 & 0.004 & 0.006 \\
\hline Current marital status: widowed & 0.255 & 0.382 & 0.166 & 0.265 \\
\hline Current marital status: divorced & 0.143 & 0.110 & 0.012 & 0.008 \\
\hline Number of observations & 2,974 & 1,958 & 1,639 & 1,063 \\
\hline
\end{tabular}

Notes: See notes to Table 2. Reported Social Security benefits are multiplied by the ratio of the Average Wage Index (AWI) in 1995 to the AWI when the person was aged 60, and by the ratio of the CPI-W in 2013 to the CPI-W in 1995. Other sources of income are adjusted to 2013 dollars using the CPI-U. We use an adjusted poverty measure that preserves the observed poverty rate, by adjusting the poverty threshold for each sample so that the poverty rate based on indexed benefits and other income is identical to the observed poverty rate absent the counterfactual adjustment. (That is why we show both the unadjusted and adjusted figures, even though they are the same.) The samples for "Women with Husbands" are slightly larger than those reported below for the income threshold regressions because observations that reside in a nursing home are assigned a missing value for the income threshold/poverty variable. 
Table 4: The Effect of the 2000 Elimination of the Retirement Earnings Test on the Age at Claiming Benefits in Months, Women First Observed Age 70 or Older, OLS Estimates

\begin{tabular}{|c|c|c|c|c|}
\hline & Born 1918-1942 & Born 1918-1942 & Born 1925-1940 & Born 1925-1940 \\
\hline Dependent variable: & $\begin{array}{l}\text { Age at claiming } \\
\text { in months }\end{array}$ & $\begin{array}{l}\text { Age at claiming } \\
\text { in months }\end{array}$ & $\begin{array}{c}\text { Age at claiming } \\
\text { in months }\end{array}$ & $\begin{array}{l}\text { Age at claiming } \\
\text { in months }\end{array}$ \\
\hline & $(1)$ & $(2)$ & (3) & (4) \\
\hline Less than age 70 in 2000 & $\begin{array}{c}-9.03 * * * \\
(0.87)\end{array}$ & & $\begin{array}{c}-7.72 * * * \\
(0.87)\end{array}$ & \\
\hline Aged 69 in 2000 & & $\begin{array}{c}-7.83 * * * \\
(1.56)\end{array}$ & & $\begin{array}{c}-6.54 * * * \\
(1.53)\end{array}$ \\
\hline Aged 68 in 2000 & & $\begin{array}{c}-7.96 * * * \\
(1.57)\end{array}$ & & $\begin{array}{c}-6.67 * * * \\
(1.55)\end{array}$ \\
\hline Aged 67 in 2000 & & $\begin{array}{l}-10.03^{* * *} \\
(1.61)\end{array}$ & & $\begin{array}{c}-8.73^{* * *} \\
(1.59)\end{array}$ \\
\hline Aged 66 in 2000 & & $\begin{array}{c}-8.83 * * * \\
(1.59)\end{array}$ & & $\begin{array}{c}-7.53^{* * *} \\
(1.57)\end{array}$ \\
\hline $\begin{array}{l}\text { Aged } 65 \text { or younger } \\
\text { in } 2000\end{array}$ & & $\begin{array}{c}-9.55 * * * \\
(1.07)\end{array}$ & & $\begin{array}{c}-8.23 * * * \\
(1.06)\end{array}$ \\
\hline Number of observations & 2,974 & 2,974 & 2,742 & 2,742 \\
\hline
\end{tabular}

Notes: See notes to Tables 2 and 3. Asterisks denote levels of significance: $1 \%\left({ }^{* * *}\right)$ level of significance; 5\% (**) level of significance; and $10 \%\left(^{*}\right)$ level of significance. The outcome variable is the age in months that the individual began claiming Social Security benefits. The sample includes the first observation of the individual at ages 70 or 71 . Only female observations are included in the sample. The specification also includes dummy variables for education (high school or GED, some college, college degree (BA) and above), race (black, white), marital status (married, partnered, widowed), and FRA greater than age 65. 
Table 5: The Effect of the 2000 Elimination of the Retirement Earnings Test on Women's Benefits, Women First Observed Age 70 or Older, OLS Estimates

\begin{tabular}{|c|c|c|c|c|}
\hline & Born 1918-1942 & Born 1918-1942 & Born 1925-1940 & Born 1925-1940 \\
\hline Dependent variable: & Annual benefits & Annual benefits & Annual benefits & Annual benefits \\
\hline & $(1)$ & $(2)$ & $(3)$ & $(4)$ \\
\hline Less than age 70 in 2000 & $\begin{array}{c}-807.68 * * * \\
(246.89)\end{array}$ & & $\begin{array}{c}-642.46 * * * \\
(246.87)\end{array}$ & \\
\hline Aged 69 in 2000 & & $\begin{array}{l}-803.03 * \\
(439.92)\end{array}$ & & $\begin{array}{l}-645.20 \\
(435.72)\end{array}$ \\
\hline Aged 68 in 2000 & & $\begin{array}{l}-546.91 \\
(444.36)\end{array}$ & & $\begin{array}{l}-388.36 \\
(440.12)\end{array}$ \\
\hline Aged 67 in 2000 & & $\begin{array}{l}-698.78 \\
(455.28)\end{array}$ & & $\begin{array}{l}-532.52 \\
(450.93)\end{array}$ \\
\hline Aged 66 in 2000 & & $\begin{array}{c}6.94 \\
(449.12)\end{array}$ & & $\begin{array}{c}162.88 \\
(444.79)\end{array}$ \\
\hline $\begin{array}{l}\text { Aged } 65 \text { or younger } \\
\text { in } 2000\end{array}$ & & $\begin{array}{c}-1,192.34 * * * \\
(301.51)\end{array}$ & & $\begin{array}{c}-1,019.94 * * * \\
(300.15)\end{array}$ \\
\hline Number of observations & 2,974 & 2,974 & 2,742 & 2,742 \\
\hline
\end{tabular}

Notes: See notes to Tables 2, 3, and 4. 
Table 6: The Effect of the 2000 Elimination of the Retirement Earnings Test on the Age at Claiming Benefits in Months, and Family Benefits, Women with Husband Observed, Women First Observed Age 70 or Older, Born 19251940, OLS Estimates

\begin{tabular}{|c|c|c|c|c|c|}
\hline Dependent variable: & $\begin{array}{l}\text { Age at } \\
\text { claiming in } \\
\text { months }\end{array}$ & $\begin{array}{l}\text { Age at } \\
\text { claiming in } \\
\text { months }\end{array}$ & $\begin{array}{l}\text { Husband's age } \\
\text { at claiming in } \\
\text { months }\end{array}$ & $\begin{array}{l}\text { Husband's age } \\
\text { at claiming in } \\
\text { months }\end{array}$ & $\begin{array}{l}\text { Annual } \\
\text { family } \\
\text { benefits }\end{array}$ \\
\hline & (1) & $(2)$ & (3) & $(4)$ & $(5)$ \\
\hline Less than age 70 in 2000 & $\begin{array}{c}-10.31^{* * *} \\
(1.35)\end{array}$ & & $\begin{array}{l}-0.11 \\
(1.62)\end{array}$ & & $\begin{array}{l}2,740.26 * * * \\
\quad(656.54)\end{array}$ \\
\hline Aged 69 in 2000 & & $\begin{array}{c}-7.57 * * * \\
(2.08)\end{array}$ & & $\begin{array}{l}-2.56 \\
(2.50)\end{array}$ & \\
\hline Aged 68 in 2000 & & $\begin{array}{c}-10.49 * * * \\
(2.04)\end{array}$ & & $\begin{array}{l}-1.53 \\
(2.45)\end{array}$ & \\
\hline Aged 67 in 2000 & & $\begin{array}{c}-10.33^{* * *} \\
(2.13)\end{array}$ & & $\begin{array}{l}5.06^{* *} \\
(2.55)\end{array}$ & \\
\hline Aged 66 in 2000 & & $\begin{array}{l}-10.87 * * * \\
(2.20)\end{array}$ & & $\begin{array}{c}2.97 \\
(2.63)\end{array}$ & \\
\hline Aged 65 or younger in 2000 & & $\begin{array}{c}-11.93^{* * *} \\
(1.69)\end{array}$ & & $\begin{array}{l}-1.51 \\
(2.02)\end{array}$ & \\
\hline $\begin{array}{l}\text { Husband less than age } 70 \\
\text { in } 2000\end{array}$ & $\begin{array}{c}1.79 \\
(1.22)\end{array}$ & & $\begin{array}{c}-7.92 * * * \\
(1.46)\end{array}$ & & $\begin{array}{l}-4,243.99 * * * \\
(593.42)\end{array}$ \\
\hline Husband Aged 69 in 2000 & & $\begin{array}{c}1.58 \\
(1.98)\end{array}$ & & $\begin{array}{c}-7.73 * * * \\
(2.38)\end{array}$ & \\
\hline Husband Aged 68 in 2000 & & $\begin{array}{l}-0.75 \\
(2.13)\end{array}$ & & $\begin{array}{c}-5.35^{* *} \\
(2.55)\end{array}$ & \\
\hline Husband Aged 67 in 2000 & & $\begin{array}{l}4.33^{*} \\
(2.28)\end{array}$ & & $\begin{array}{l}-6.03^{* *} \\
(2.73)\end{array}$ & \\
\hline Husband Aged 66 in 2000 & & $\begin{array}{l}3.77^{*} \\
(2.26)\end{array}$ & & $\begin{array}{l}-8.26 * * * \\
(2.70)\end{array}$ & \\
\hline $\begin{array}{l}\text { Husband Aged } 65 \text { or younger in } \\
2000\end{array}$ & & $\begin{array}{l}3.49 * \\
(1.80)\end{array}$ & & $\begin{array}{c}-9.70 * * * \\
(2.16)\end{array}$ & \\
\hline $\begin{array}{l}\text { Combined effect of husband } \\
\text { and wife less than age } 70 \text { in } \\
2000\end{array}$ & & & & & $\begin{array}{l}-1,503.73^{* *} \\
(655.68)\end{array}$ \\
\hline
\end{tabular}

Notes: $N=1,530$. See notes to Tables 2, 3, and 4. The sample is further limited to women whose husband's age at claiming age is not missing and is between the ages of 62 and 71, and who report a unique husband. Those observations that report multiple husbands complicate matters because it is unclear which husband's age affects the woman's benefit. Women who only report a spouse when "partnered" are also excluded from the sample. A separate control is included for husband's FRA greater than age 65. 
Table 7: The Effect of the 2000 Elimination of the Retirement Earnings Test on Poverty, Women First Observed and Women with Husband Observed Age 70 or Older and 75 or Older Samples, Born 1925-1940, OLS Estimates

\begin{tabular}{|c|c|c|c|c|c|c|}
\hline Dependent variable: & $\begin{array}{c}\text { Income } \\
<150 \% \text { of } \\
\text { poverty line } \\
\end{array}$ & $\begin{array}{c}\text { Income } \\
<150 \% \text { of } \\
\text { poverty line } \\
\end{array}$ & $\begin{array}{c}\text { Income } \\
<200 \% \text { of } \\
\text { poverty line } \\
\end{array}$ & $\begin{array}{c}\text { Income } \\
<200 \% \text { of } \\
\text { poverty line }\end{array}$ & $\begin{array}{c}\text { Income } \\
<150 \% \text { of } \\
\text { poverty line } \\
\end{array}$ & $\begin{array}{c}\text { Income } \\
<200 \% \text { of } \\
\text { poverty line } \\
\end{array}$ \\
\hline Women: & All & All & All & All & $\begin{array}{l}\text { Husband } \\
\text { observed }\end{array}$ & $\begin{array}{l}\text { Husband } \\
\text { observed }\end{array}$ \\
\hline & $(1)$ & $(2)$ & (3) & (4) & $(5)$ & $(6)$ \\
\hline \multicolumn{7}{|c|}{ A. Women first observed age 70 or older } \\
\hline Less than age 70 in 2000 & $\begin{array}{l}-0.0265^{*} \\
(0.0136)\end{array}$ & & $\begin{array}{l}-0.0314^{*} \\
(0.0162)\end{array}$ & & $\begin{array}{l}-0.0165 \\
(0.0147)\end{array}$ & $\begin{array}{l}-0.0104 \\
(0.0227)\end{array}$ \\
\hline Aged 69 in 2000 & & $\begin{array}{l}-0.0118 \\
(0.0239)\end{array}$ & & $\begin{array}{l}-0.0166 \\
(0.0286)\end{array}$ & & \\
\hline Aged 68 in 2000 & & $\begin{array}{l}-0.0163 \\
(0.0243)\end{array}$ & & $\begin{array}{l}-0.0028 \\
(0.0290)\end{array}$ & & \\
\hline Aged 67 in 2000 & & $\begin{array}{c}-0.0491^{* *} \\
(0.0248)\end{array}$ & & $\begin{array}{l}-0.0090 \\
(0.0296)\end{array}$ & & \\
\hline Aged 66 in 2000 & & $\begin{array}{l}-0.0392 \\
(0.0245)\end{array}$ & & $\begin{array}{c}-0.0659 * * \\
(0.0293)\end{array}$ & & \\
\hline $\begin{array}{l}\text { Aged } 65 \text { or younger in } \\
2000\end{array}$ & & $\begin{array}{l}-0.0236 \\
(0.0165)\end{array}$ & & $\begin{array}{l}-0.0418^{* *} \\
(0.0198)\end{array}$ & & \\
\hline $\begin{array}{l}\text { Husband less than age } 70 \\
\text { in } 2000\end{array}$ & & & & & $\begin{array}{c}0.0295 * * \\
(0.0133)\end{array}$ & $\begin{array}{l}-0.0040 \\
(0.0205)\end{array}$ \\
\hline $\begin{array}{l}\text { Combined effect of } \\
\text { husband and wife less } \\
\text { than age } 70 \text { in } 2000\end{array}$ & & & & & $\begin{array}{c}0.0130 \\
(0.0146)\end{array}$ & $\begin{array}{c}-0.0143 \\
0.0226\end{array}$ \\
\hline Number of observations & 2,721 & 2,721 & 2,721 & 2,721 & 1,522 & 1,522 \\
\hline \multicolumn{7}{|c|}{ B. Women first observed age 75 or older } \\
\hline Less than age 70 in 2000 & $\begin{array}{l}0.0283 * \\
(0.0167)\end{array}$ & & $\begin{array}{l}0.0369 * \\
(0.0190)\end{array}$ & & $\begin{array}{l}0.0360^{*} \\
(0.0208)\end{array}$ & $\begin{array}{l}0.0660^{* *} \\
(0.0280)\end{array}$ \\
\hline Aged 69 in 2000 & & $\begin{array}{c}0.0230 \\
(0.0291)\end{array}$ & & $\begin{array}{l}-0.0207 \\
(0.0329)\end{array}$ & & \\
\hline Aged 68 in 2000 & & $\begin{array}{c}0.0211 \\
(0.0284)\end{array}$ & & $\begin{array}{c}0.0085 \\
(0.0321)\end{array}$ & & \\
\hline Aged 67 in 2000 & & $\begin{array}{c}0.0256 \\
(0.0352)\end{array}$ & & $\begin{array}{c}0.0258 \\
(0.0397)\end{array}$ & & \\
\hline Aged 66 in 2000 & & $\begin{array}{c}0.0014 \\
(0.0291)\end{array}$ & & $\begin{array}{l}-0.0048 \\
(0.0329)\end{array}$ & & \\
\hline $\begin{array}{l}\text { Aged } 65 \text { or younger in } \\
2000\end{array}$ & & $\begin{array}{c}0.0503^{* *} \\
(0.0228)\end{array}$ & & $\begin{array}{c}0.1087 * * * \\
(0.0257)\end{array}$ & & \\
\hline $\begin{array}{l}\text { Husband less than age } 70 \\
\text { in } 2000\end{array}$ & & & & & $\begin{array}{l}-0.0031 \\
(0.0212) \\
\end{array}$ & $\begin{array}{r}0.0007 \\
(0.0285) \\
\end{array}$ \\
\hline $\begin{array}{l}\text { Combined effect of } \\
\text { husband and wife less } \\
\text { than age } 70 \text { in } 2000\end{array}$ & & & & & $\begin{array}{c}0.0328 \\
(0.0211)\end{array}$ & $\begin{array}{c}0.0667 * * \\
(0.0284)\end{array}$ \\
\hline Number of observations & 1,781 & 1,781 & 1,781 & 1,781 & 1,003 & 1,003 \\
\hline
\end{tabular}

Notes: $N=1,781$. See notes to Tables 2, 3, 4, and 6. Poverty is based on the sum of adjusted Social Security benefits and other income relative to the poverty line (all in 2013 dollars). Note that relative to the corresponding earlier tables, we lose a small number of observations because they reside in a nursing home and are assigned a missing value for poverty. (The RAND HRS provides an indicator for whether those living in institutionalized facilities are living in poverty. We view this measure as less salient for policy analysis regarding income support provided by Social Security. Individuals residing in institutionalized facilities are likely worse off due to considerations other than income and may be required to spend a large amount of resources on care.) All women in the age 75 sample (Panel B) have an FRA equal to age 65. As a result, the "FRA greater than age 65" variable is excluded from the specifications in this panel. 
Appendix Table A1: Percentage of Women Age 62 or Older by Type of Entitlement and Year

\begin{tabular}{cccccc}
\hline & Entitled worker only & \multicolumn{2}{c}{ Dually-entitled } & Spouse only & Survivor only \\
\hline \multicolumn{5}{c}{ Spouse } & Survivor \\
\hline 1995 & 36.2 & 11.5 & 14.4 & 14.3 & 23.6 \\
2000 & 38.0 & 12.0 & 15.6 & 12.9 & 21.5 \\
2005 & 41.4 & 12.0 & 16.0 & 11.4 & 19.3 \\
2010 & 46.3 & 12.1 & 15.5 & 9.6 & 16.4 \\
2011 & 47.5 & 12.0 & 15.3 & 9.3 & 15.9 \\
2013 & 48.7 & 11.9 & 15.1 & 9.0 & 15.3 \\
\hline
\end{tabular}

Source: Data from the Social Security Administration’s Annual Statistical Supplement, 2013, Table 5.A14.

Appendix Table A2: Discrepancies between Claiming Ages/Dates in Self-Reported and Linked Administrative Data

\begin{tabular}{lccc}
\hline & & Respondents born before & Respondents born in 1931 or \\
Diff = Public - Admin. & $(1)$ & 1931 & $(3)$ \\
\hline Less than -12 months & 49 & $(2)$ & 23 \\
-4 to -12 months & 138 & 26 & 101 \\
-1 to -3 months & 367 & 37 & 290 \\
No difference & 1,134 & 77 & 843 \\
1 to 3 months & 1,707 & 291 & 1,488 \\
4 to 12 months & 699 & 219 & 407 \\
13 or more months & 427 & 292 & 155 \\
\hline Mean & 3.9 & 272 & 2.1 \\
Standard Deviation & 10.9 & 17.0 & 6.7 \\
\hline
\end{tabular}

Notes: The sample in the table contains all individuals who have agreed to have their Social Security records linked to their HRS survey responses. The sample is limited to those individuals who have never claimed disability benefits and whose current and initial claiming type is equal to a retired worker benefit. Any individuals who are receiving a second benefit based on another individual's account, whose beneficiary date of birth is not equal to the account holder's date of birth, whose "historical current entitlement code" is equal to disabled, whose date of current entitlement does not equal the date of initial entitlement, or whose age at claiming in the administrative data is calculated to be less than age 62 , are removed from the sample. Finally, the sample is limited to those whose self-reported age at claiming (in months) is between 744 and 851 (inclusive).

Appendix Table A3: The Effect of the 2000 Elimination of the Retirement Earnings Test on Benefit Entitlement, Song and Manchester (2007) Replication, Probit and OLS Estimates

\begin{tabular}{|c|c|c|c|c|}
\hline \multirow[t]{3}{*}{$\begin{array}{l}\text { Song and Manchester } \\
\text { (2007) results: }\end{array}$} & \multicolumn{4}{|c|}{ Between 0.0219 and 0.0502} \\
\hline & \multicolumn{2}{|c|}{ OLS } & \multicolumn{2}{|c|}{ Probit } \\
\hline & $\begin{array}{l}\text { Public data } \\
\text { (1) }\end{array}$ & $\begin{array}{l}\text { SSA admin. data } \\
\text { (2) }\end{array}$ & $\begin{array}{l}\text { Public data } \\
\text { (3) }\end{array}$ & $\begin{array}{l}\text { SSA admin. data } \\
\text { (4) }\end{array}$ \\
\hline Attained ages 65-69 & $\begin{array}{c}0.0469 * * * \\
(0.0102)\end{array}$ & $\begin{array}{c}-0.0082 \\
(0.0106)\end{array}$ & $\begin{array}{c}0.0669 * * * \\
(0.0113)\end{array}$ & $\begin{array}{c}0.0022 \\
(0.0094)\end{array}$ \\
\hline Number of observations & 19,644 & 13,779 & 19,644 & 13,779 \\
\hline \multicolumn{5}{|c|}{$\begin{array}{l}\text { Notes: The samples include both men and women. The Song and Manchester results presented in the table are from } \\
\text { Table 4, p. 686, Model II (the base model). In their analysis, Song and Manchester (2007) use two separate control } \\
\text { groups. One group of the treatment groups includes those who had attained ages } 65 \text { to } 69 \text { by January } 1 \text { of the calendar } \\
\text { year. The second treatment group includes those who turn age } 65 \text { during the year. The younger control group contains } \\
\text { those who turn age } 62 \text { to age } 64 \text { during the year. The older control group contains those who have attained ages } 70 \text { to } \\
72 \text { as of January } 1 \text { of the calendar year. Their regressions include interaction of treatment status with year dummies, } \\
\text { dummies for being in the younger or older control group, calendar year dummies, an indicator for whether the person- } \\
\text { year observation is male, and an indicator for whether the person-year observation is white. In the above replication } \\
\text { analysis, standard errors are clustered at the individual level. For probit estimates, marginal effects evaluated at sample } \\
\text { means and varying the treatment variable from zero to one are reported. }\end{array}$} \\
\hline
\end{tabular}

